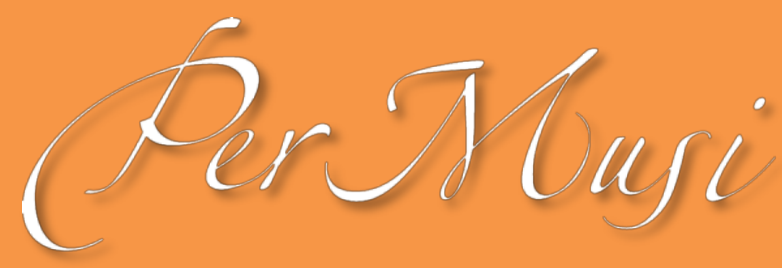

eISSN 2317-6377

\title{
Uma cor que desentorte o arco-íris
}

\author{
Danilo Bogo \\ https://orcid.org/0000-0002-5831-5545 \\ Universidade Federal da Integração Latino-Americana \\ danilobogo@gmail.com
}

MUSIC SCORE

Submitted date: 27 oct 2021

Final approval date: 19 nov 2021

Resumo: Com duração de aproximadamente 6'30" a peça foi escrita em 2017 para piano e eletrônica, tendo a proporção áurea - e suas ramificações como a sequência Fibonacci - como inspiração para a organização da harmonia e da forma. O piano assume um caráter solista e a eletrônica - operada por dois intérpretes em dois computadores mistura sons fixados (eletrônica diferida - escritos em língua portuguesa na partitura) e síntese gerada pelo software SuperCollider (live electronics - escritos em inglês) em ambos os computadores. Os sons fixados (pássaros, avião, chuva etc.) são misturados em tempo real pelos dois intérpretes com o auxílio de um mixer enquanto os live electronics (síntese) são controlados pelo mouse e enviados também ao mixer. Os elementos do piano são tratados como "objetos sonoros" que se adensam pouco a pouco até atingir dois clímaces pré-estabelecidos pela sequência Fibonacci.

Palavras-chave: Eletrônica mista; Piano; Supercollider; Proporção áurea; Escrita para mouse.

\section{TITLE: A COLOR WHICH UNBENDS THE RAINBOW}

Abstract: Having approximately 6'30" of length this piece was written in 2017 for piano and electronics. It has golden rate - and its ramifications like Fibonacci sequence - as an inspiration to organize harmony and form. Piano assumes a solo character and the electronics - operated by two performers in two PCs - mixes fixed sounds (written in Portuguese on the score) and live electronics synthesis generated by the SuperCollider software (these ones written in English) in both computers. Fixed sounds (birds, airplane, rain etc.) are mixed in real time by both electronic performers via a mixer while live electronics (synthesis) are controlled by computer mouse and also sent to the mixer. Piano elements are treated like "sound objects" which become denser, little by little, until reach two climaxes preestablished by the Fibonacci sequence.

Keywords: Mixed music; Piano; Supercollider; Golden rate; Mouse writing.

(9) (1) 


\section{Uma cor que desentorte o arco-íris}

Danilo Bogo, Universidade Federal da Integração Latino-Americana, danilobogo@gmail.com

\section{Apresentação}

\subsection{Contexto}

Com duração de aproximadamente 6'30" a peça foi escrita em 2017 para piano e eletrônica, tendo a proporção áurea - e suas ramificações como a sequência Fibonacci - como inspiração para a organização da harmonia e da forma. A peça surge como encomenda do Grupo Contackte para composição de uma peça mista que utilizasse o SuperCollider como suporte da eletrônica. A ideia era conhecer o software, criar com ele e para ele. A peça estreia em 2017 no primeiro encontro de composição da UNILA (Universidade Federal da Integração Latino-americana) tendo a musicista Andressa Castilho ao piano. No mesmo ano é executada no evento Musicircus no Sesc-Foz de Iguaçu-PR e ganha uma versão de estúdio pelo próprio compositor ${ }^{1}$.

Idealizado pelo compositor Cristiano Galli em 2015, o Grupo Contackte é um grupo independente radicado em Foz do Iguaçu (PR), na fronteira entre Paraguai, Brasil e Argentina. O grupo iniciou suas atividades em 2016 se apresentando como uma plataforma de fomento da arte contemporânea tendo como objetivo a colaboração entre diversas áreas artísticas e tecnológicas - como música, artes visuais, informática, dança etc. Desta maneira o grupo congrega compositores, instrumentistas, artistas visuais, cineastas, especialistas nas áreas de informática e está sempre aberto a novas manifestações tecnológico-artísticas.

O título "Uma cor que desentorte o arco-íris" vem da ideia de causar um "tilt" na lógica do pensamento e acompanha outras obras compostas no período. A peça tem o céu como inspiração, seja na sua forma em arco (-íris), seja nos sons escolhidos na eletrônica: sons sintéticos do SuperCollider (pássaros, tempestade, eletricidade etc.) mas sobretudo nos gravados (avião, chuva, trovão e pássaros). Os limites que definem o céu também aparecem (deserto e oceano) e remetem aos sons graves do piano (chão) em oposição aos sempre presentes superagudos - soando como estrelas cintilantes. Arco-íris, chuva e luz, formando uma ponte curva entre céu e terra. Também o incomodo, uma cor intrusa, estranha, ilógica.

\subsection{Construções, expressões, inspirações...}

As alturas são organizadas a partir de duas ideias harmônicas (grupos). O primeiro grupo harmônico foi construído a partir de uma extensão de 75 notas no piano (de C-0 a D-6) ${ }^{2}$ e a prática de multiplicar para

${ }^{1}$ Para versão de estúdio ver https://youtu.be/ev81E78A9W4?t=44. Acesso 25 de novembro de 2021.

${ }^{2}$ C3 como Dó central. 
encontrar a seção áurea (por 0.618 para descobrir a parte maior ou 0.383 para a menor) foi aplicada sucessivamente para obter notas internas a esses extremos e definir uma "escala geral" do primeiro grupo harmônico. Em resumo, após o resultado da primeira multiplicação, toma-se uma das partes e se multiplica mais uma vez e assim sucessivamente até que o resultado não remeta à nenhuma nota (números menores que 1). Em seguida as distâncias entre os primeiros números da sequência Fibonacci $(1,2,3,5,8)$ foram aplicadas para gerar o segundo grupo harmônico. 0 eixo foi estipulado sobre o número 8 , dessa forma se vai de 1 a 8 e de 8 a 1 por toda a extensão do instrumento.

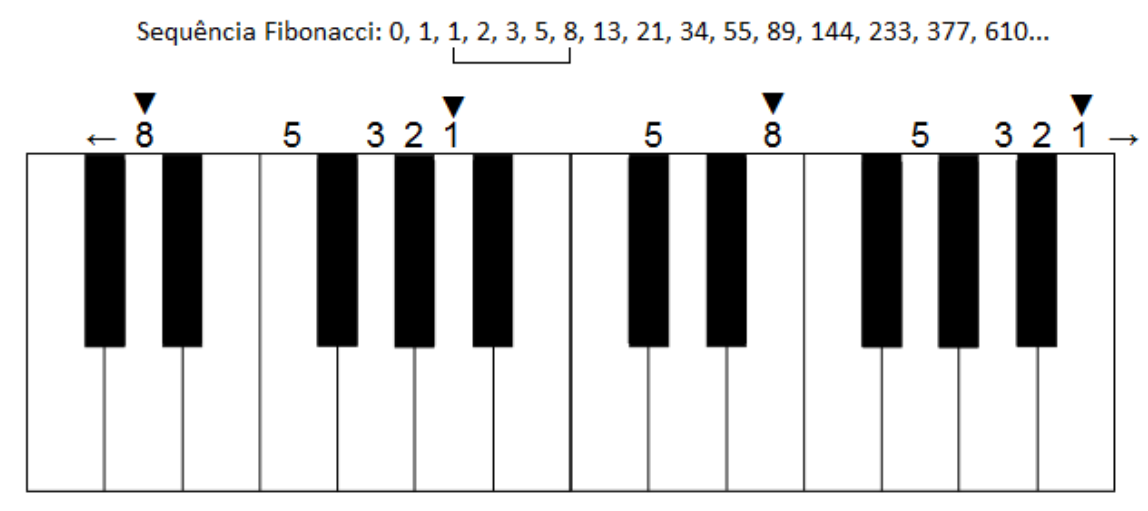

Figura 1 - Excerto da série Fibonacci aplicada às teclas do piano

Um procedimento semelhante foi empregado para a forma. A peça dura 377 segundos e os elementos do piano são tratados como objetos sonoros que se adensam pouco a pouco até atingir dois clímaces préestabelecidos pela sequência Fibonacci (fim da seção A: 89" - vídeo 2'14"; e fim da seção C: 233" - vídeo $\left.4^{\prime} 38^{\prime \prime \prime}\right)$.

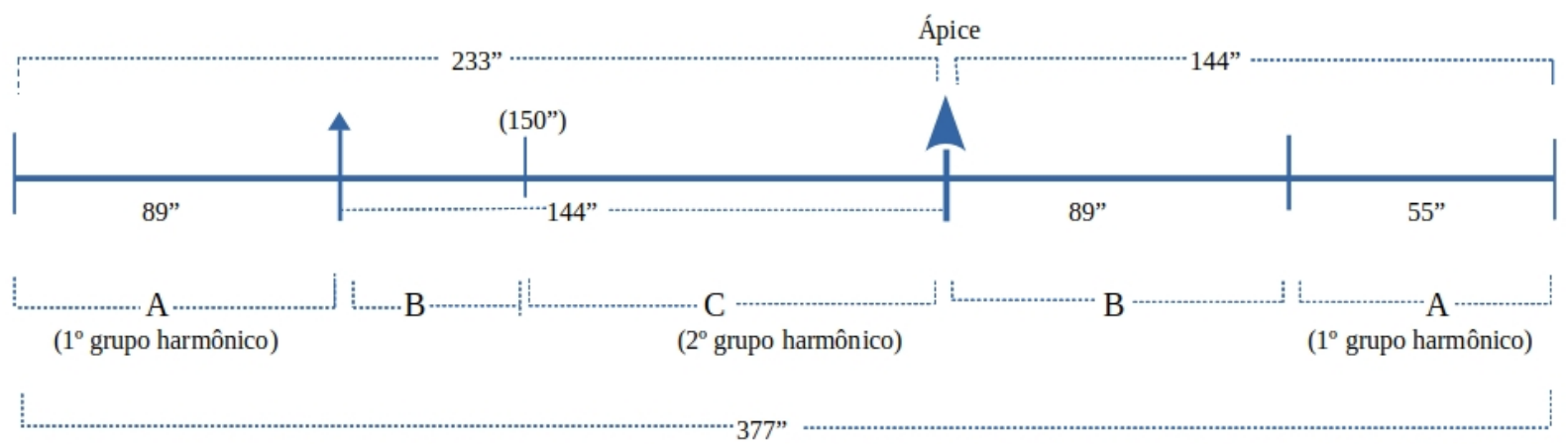

Figura 2 - Forma de Uma cor que desentorte o arco-íris. Observa-se que suas seções são organizadas em números áureos

O piano assume um caráter solista e a eletrônica - operada por dois intérpretes em dois computadores mistura sons fixados (eletrônica diferida - escritos em língua portuguesa na partitura) e síntese gerada pelo software SuperCollider (live electronics - escritos em inglês) em ambos os computadores. Sobre a eletrônica, foi utilizado o software Supercollider para gerar síntese e como player para executar sons e paisagens sonoras (encontradas em freesound.org). O SuperCollider é um software livre e os códigos apresentados na partitura estão disponíveis, também de forma gratuita, em sccode.org. Importante salientar que os códigos

\footnotetext{
${ }^{3}$ Ver link do YouTube na 1a nota de rodapé. O segundo número é referente à minutagem do vídeo em questão.
} 
não foram desenvolvidos por mim, mas foram escolhidos após intensa busca com o intuito de atender as demandas composicionais.

\subsection{Grafia}

Buscando uma interpretação um pouco mais livre do ritmo foi escolhida a escrita proporcional balizada por pequenos traços que representam a medida de um segundo. Assim, o ataque de cada nota é definido pela sua posição aproximada dentro de um segundo dado. Já a duração, no caso do piano, é controlada pelo pedal de sustain, eliminando assim a necessidade de utilização das figuras rítmicas tradicionais. Para a grafia da eletrônica se usou uma abordagem descritiva com símbolos representando cada som, exceto para a escrita para mouse de computador que é totalmente prescritiva ${ }^{4}$. Por ser algo incomum, não foi encontrada nenhuma referência de escrita para mouse. Foi necessário defini-la pois no código Sweep noise se usa o recurso "Theremin" ${ }^{5}$ onde o som é modulado dependendo da posição em que a seta do mouse se encontra na tela do computador. Assim para o parâmetro horizontal se decidiu dividir a tela em cinco partes (Figura 3 - a) e para o vertical se considera a altura no espaço onde a eletrônica é grafada (b). Dessa forma, para a Figura 3 - b se coloca o mouse na posição 4 e faz-se uma elevação até o centro da tela e se retorna, logo em seguida, à parte inferior. Já o exemplo "c" representa um movimento circular no canto inferior direito da tela com duração aproximada de dois segundos para cada ciclo.

a)

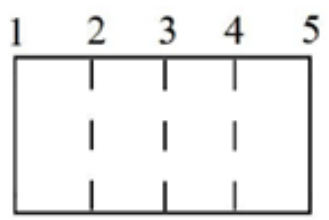

b)

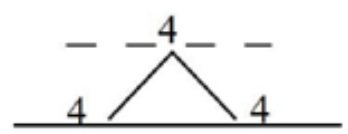

c)

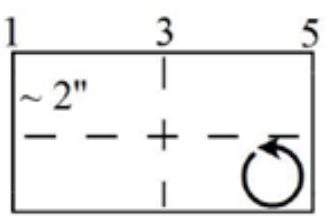

Figura 3 - Modelo de escrita para mouse utilizados na obra

Há uma preocupação no Grupo Contackte em proporcionar que seus membros de outras áreas possam participar efetivamente de uma performance musical. Por isso, no caso da peça aqui tratada, a grafia proporcional balizada em segundos permite, ao menos para a parte da eletrônica, que mesmo pessoas que não leem música possam operar os computadores e tocar junto com o/a pianista.

\section{Biografia do autor}

Graduado em violão pela Unespar/Embap, mestre em interpretação pela Universidade de Montreal (Canadá) e doutor em musicologia pela Universidade Federal do Paraná. De 2005 a 2007 integra o quarteto de violões da EMBAP realizando vários concertos pelo sul do Brasil. Suas pesquisas na área da pedagogia

\footnotetext{
${ }^{4}$ Para Segger (1997 apud Zampronha, 2000), na notação prescritiva o compositor diz ao intérprete quais ações ele deve tomar para chegar em um resultado desejado (uma tablatura, por exemplo); já na descritiva o compositor diz o resultado desejado sem indicar ao intérprete como proceder para o conseguir (ex.: escrita ortocrônica sem digitação).

${ }^{5} \mathrm{O}$ termo Theremin aqui se refere ao recurso disponível no software SuperCollider no qual é possível intervir na eletrônica em tempo real através dos movimentos do mouse de um computador. $O$ termo faz alusão ao instrumento criado pelo inventor russo Léon Theremin em 1928.
} 
instrumental dedicam-se ao desenvolvimento da leitura à primeira vista ao violão. Além de pesquisador e violonista, desenvolve intenso trabalho como compositor. Nesse quesito destaca-se a junção de música e tecnologia desenvolvida junto ao coletivo Contackte - o qual faz parte. Em outubro de 2018 o coletivo Contackte participa da Latinoware onde realiza um concerto conferência sobre música e tecnologia. Em 2016 tem um excerto de seu ciclo de canções "O amor que move o sol como as estrelas" estreado no Teatro Amazonas. Em 2017 estreia a peça "Uma cor que desentorte o arco-íris" para piano e eletrônica no primeiro encontro de composição da Unila (Universidade Federal da Integração Latino-americana). Em 2018 estreia sua peça acusmática "Objetos" no ciclo "Cê na Sexta" promovido pela Fundação Cultural de Foz do Iguaçu. Em 2020, em parceria com o cineasta Manu Reva, cria a música para o vídeo-arte "Apagandô". Esse vídeo participa, no mesmo ano, da mostra "Panorama das artes visuais da Bacia do Paraná 3" (integrando diferentes exposições no oeste paranaense) e é escolhido para integrar o Festival Atemporánea em Buenos Aires. Além dessas atividades é técnico do curso de música da Unila.

\section{Referências}

Bogo, Danilo \& Cristiano R. Galli. 2021. "Do gesto à notação: exemplos de escrita prescritiva em duas obras contemporâneas." Música em Perspectiva [Online], 10.2 (2017): sem paginação Web. 27 out 2021. doi: http://dx.doi.org/10.5380/mp.v10i2.67634.

Zampronha, Edson S. 2000. Notação, representação e composição: um novo paradigma da escritura musical. São Paulo: Annablume. 


\section{Danilo Bogo}

\section{Uma Cor que Desentorte o Arco-iris}

para piano e eletrônica 


\section{Instruções para a parte do Piano}

\section{Métrica:}

Cada compasso representa um segundo. Assim, o ritmo é definido pela posição da nota dentro de um segundo eliminando o uso de figuras rítmicas.

\section{Duração:}

A duração das notas é controlada pelo uso do pedal de sustain que é mantido pressionado por quase toda a peça. o pedal será interrompido rapidamente (sem criar silêncios) obedecendo o seguinte símbolo: 2oo. $\bumpeq$

\section{c7usters:}

Como não há figuras rítmicas optamos pelos seguintes símbolos de cluster:

П - cluster de mão o mais agudo possível em teclas brancas.

- o mesmo em teclas pretas.

$\downarrow$ - cluster de mão o mais agudo ou mais grave possível em teclas pretas e brancas (cromático).

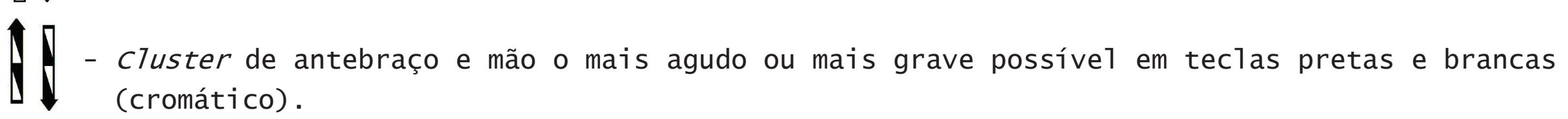




\section{Instruções para a eletrônica}

A eletrônica mistura sons gravados no ambiente (escritos em português na partitura) com sons gerados pelo software supercollider (escritos em inglês). Foi pensada para ser tocada ao vivo e controlada por dois músicos em dois computadores. A dinâmica é controlada por um mixer obedecendo os símbolos da notação tradicional. Segue o caminho que o sinal estéreo (dois canais por PC) percorre até sua saída como som:

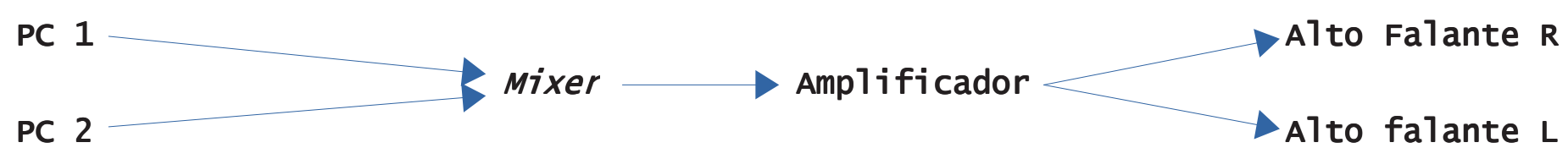

A entrada/parada de cada som são controladas pelos seguintes símbolos:

$\square=$ tocar $\square=$ parar

Sons do ambiente e seus símbolos:

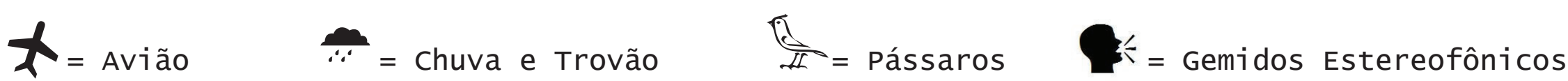

Sons do Supercol1ider:

o Suprescoollider é um software livre em ambiente de linguagem de programação para síntese de áudio. os códigos abaixo podem ser encontrados no site sccode.org. Depois de instalado, copia-se o código 
pra o ambiente do software. Após carregar o servidor (boot server) coloca-se o cursor sobre o código e pressiona-se ctr1+enter, então o som é produzido. Para pará-1o pressiona-se ctr1+ponto (ctr 1+.)

\section{Player}

Esse código transforma os sons wav em botões e facilita a execução dos sons do ambiente (Avião, Chuva e Trovão, Pássaros e Gemidos Estereofônicos). Ao clicar sobre esses botões os sons se iniciam e clicando novamente se interrompem:

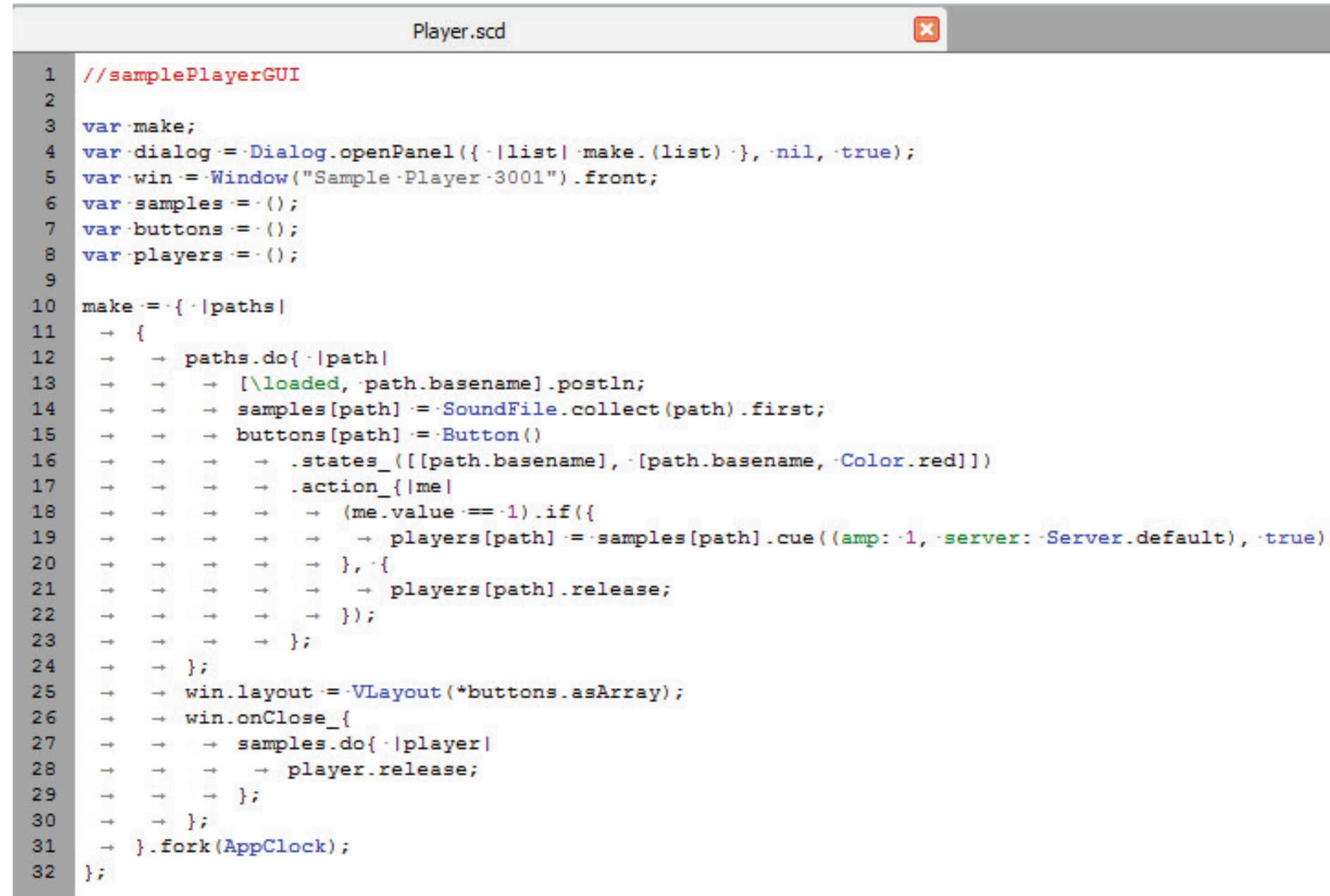




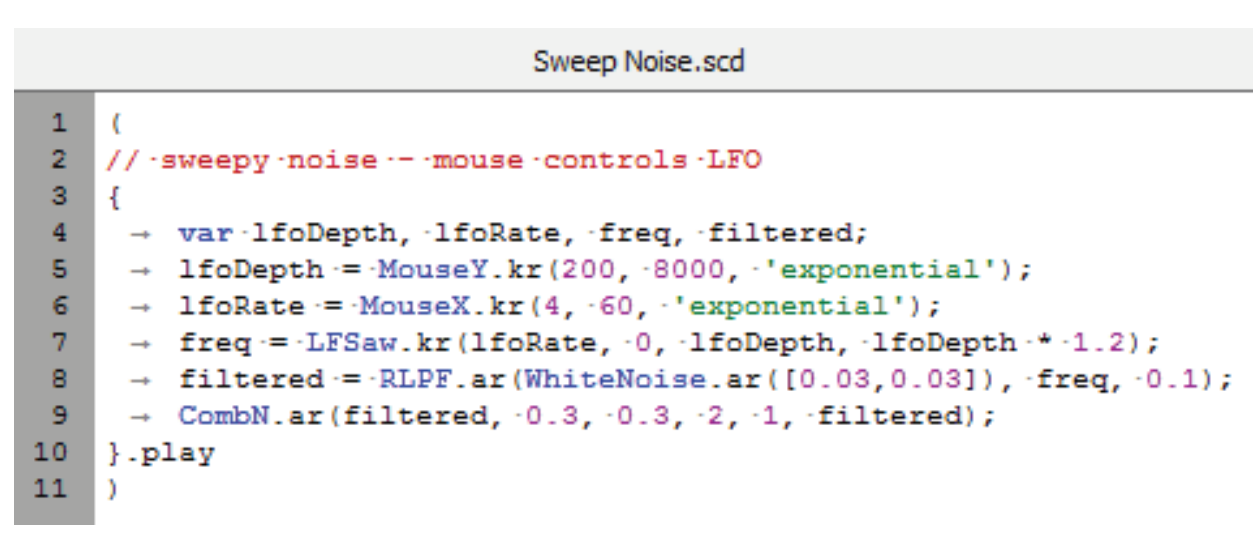

Esse código permite o controle do som em tempo real através da posição do mouse na tela do computador. 0 parâmetro horizontal é controlado pelos números de 1 a 5 representando a posição do mouse na tela (figura 1 ). 0 parâmetro vertical é controlado pela posição da linha/número no "pentagrama". Na figura 2, por exemplo, coloca-se o mouse na região 4 embaixo da tela e faz-se uma elevação até o centro da tela (linha pontilhada). A figura 3 mostra-nos uma caixa de repetição que apresenta o movimento a ser realizado e repetido quantas vezes for necessário na posição que ele aparecer (nesse caso, parte inferior da tela entre números 4 e 5). A numeração dentro da caixa indica o tempo aproximado que deve durar cada movimento. O uso de mouse externo é aconselhado no lugar dos touch pad encontrados em notebooks. Esses úttimos dificultam a realização dos movimentos devido ao seu tamanho reduzido:

Figura 1:

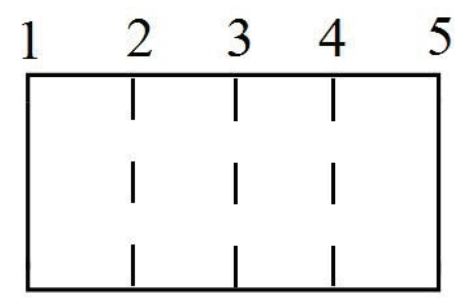

Figura 2:

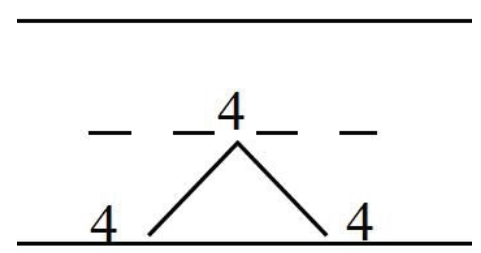

Figura 3 :

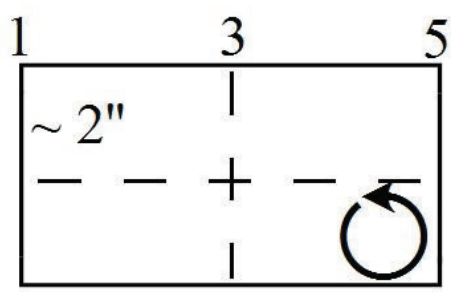




\section{Q4 $=$ Birds in Desert}

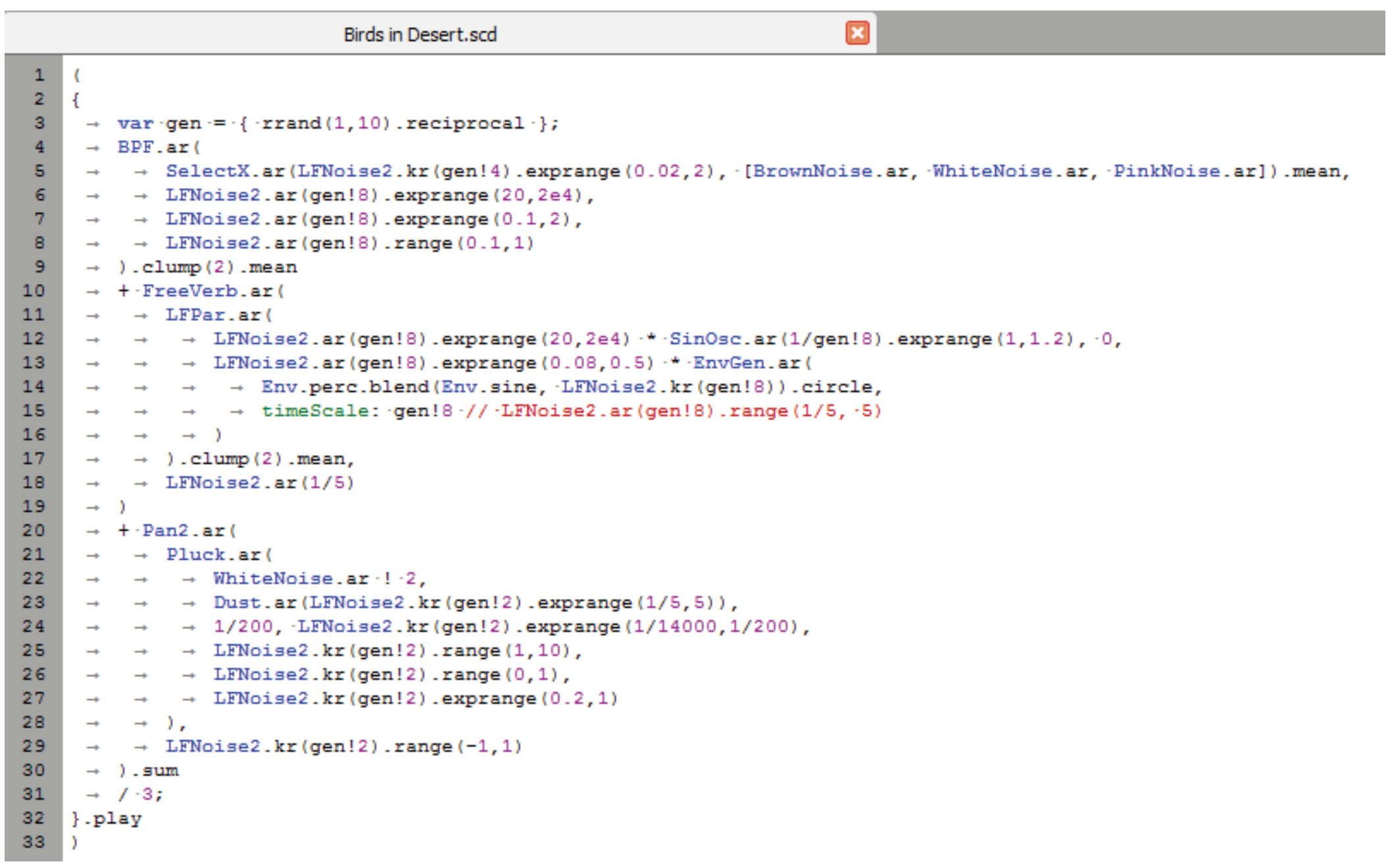




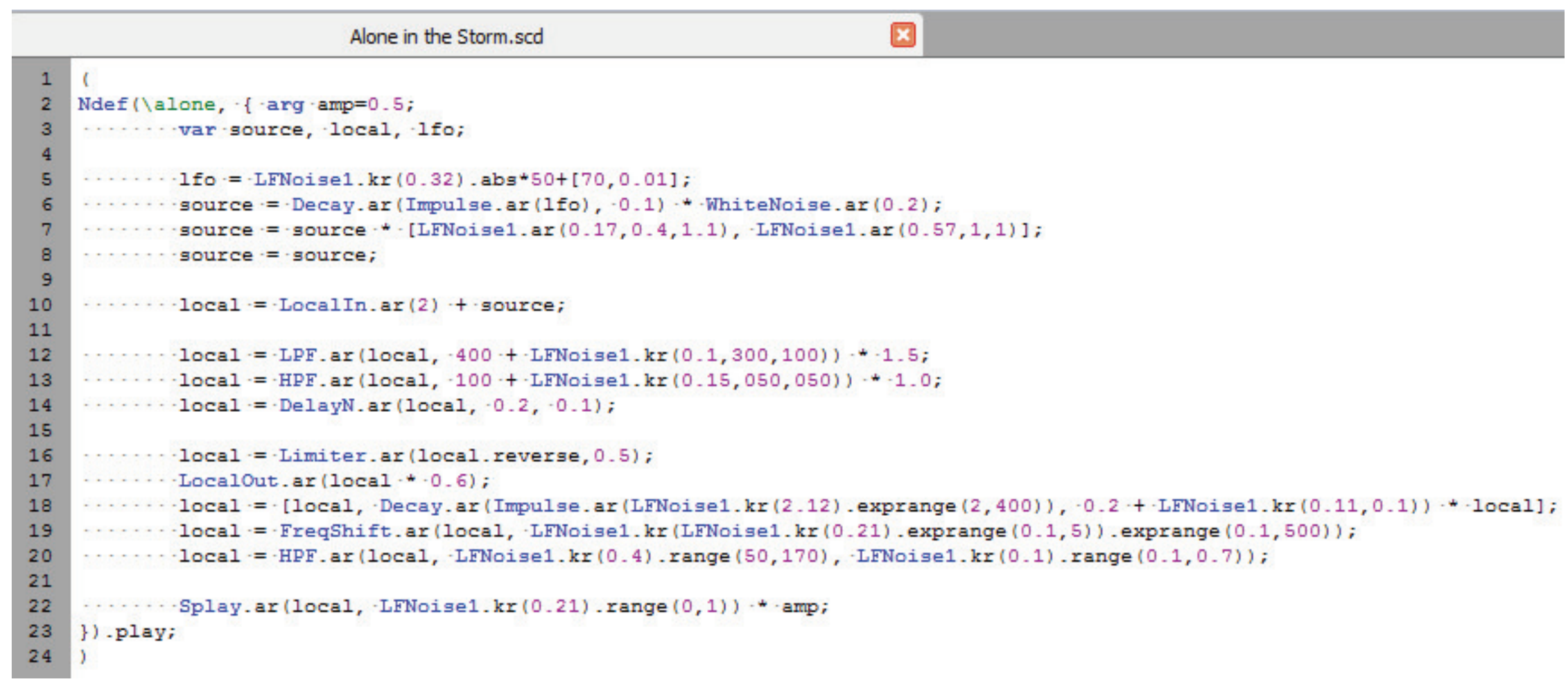




\section{$\mathcal{N}=$ Electricity}

Pressionando a primeira parte do código toca-se o Electricity. Pressionando a última parte "parar apenas Electricity" pausa-se esse código enquanto o Alone in the Storm continua tocando. Não usar ctr1+ponto (ctr1+.) nesse caso.

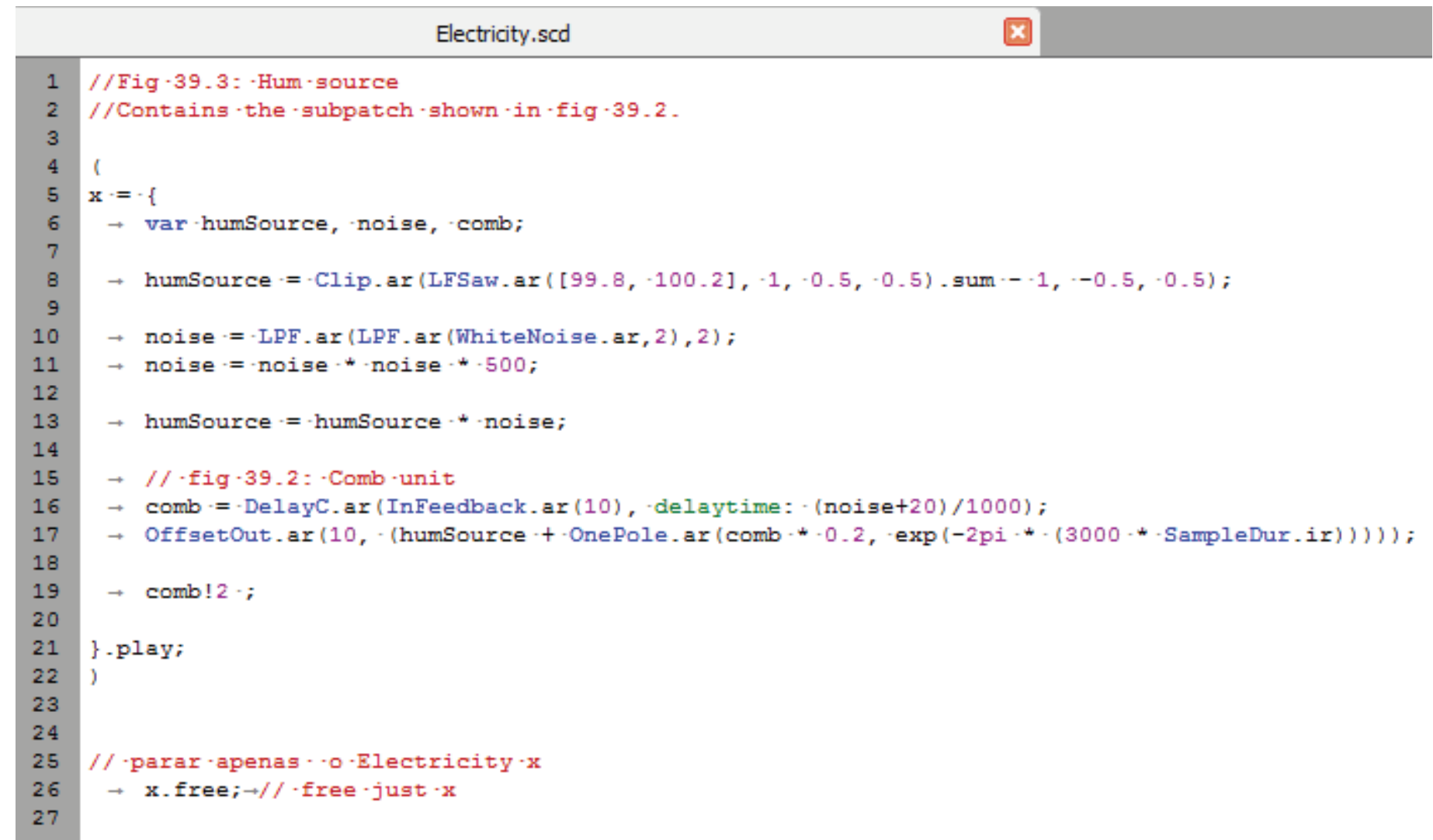


I = Breathing ocean

Breathing Ocean.scd

var-lew, bpf;

lew $=\cdot$ WhiteNoise. ar

$\rightarrow \rightarrow$ mul:0.5,

$\rightarrow \rightarrow$ add: $(0.1)$

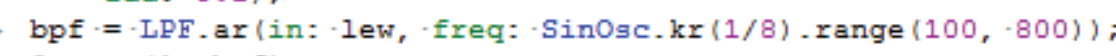

$\rightarrow$ Out.ar $(1$, bpf $)$;

\}-play;

Sons por computador:

Sons do PC 1

$\boldsymbol{\lambda}=$ Avião

$\Psi=$ Sweep Noise

Qu $=$ Birds in Desert

正= Breathing ocean
Sons do PC 2

$\because=$ Chuva e Trovão

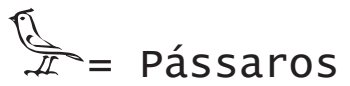

G Gemidos estereofônicos

= Alone in the storm

$N=$ Electricity

Para sons wav e dúvidas contactar danilobogo@gmai1.com 
Bogo, Danilo. "Uma cor que desentorte o arco-íris"
Per Musi no. 42, General Topics. 1-50. e224201. DOl 10.35699/2317-6377.2022.36908

Uma cor que desentorte o arco-íris

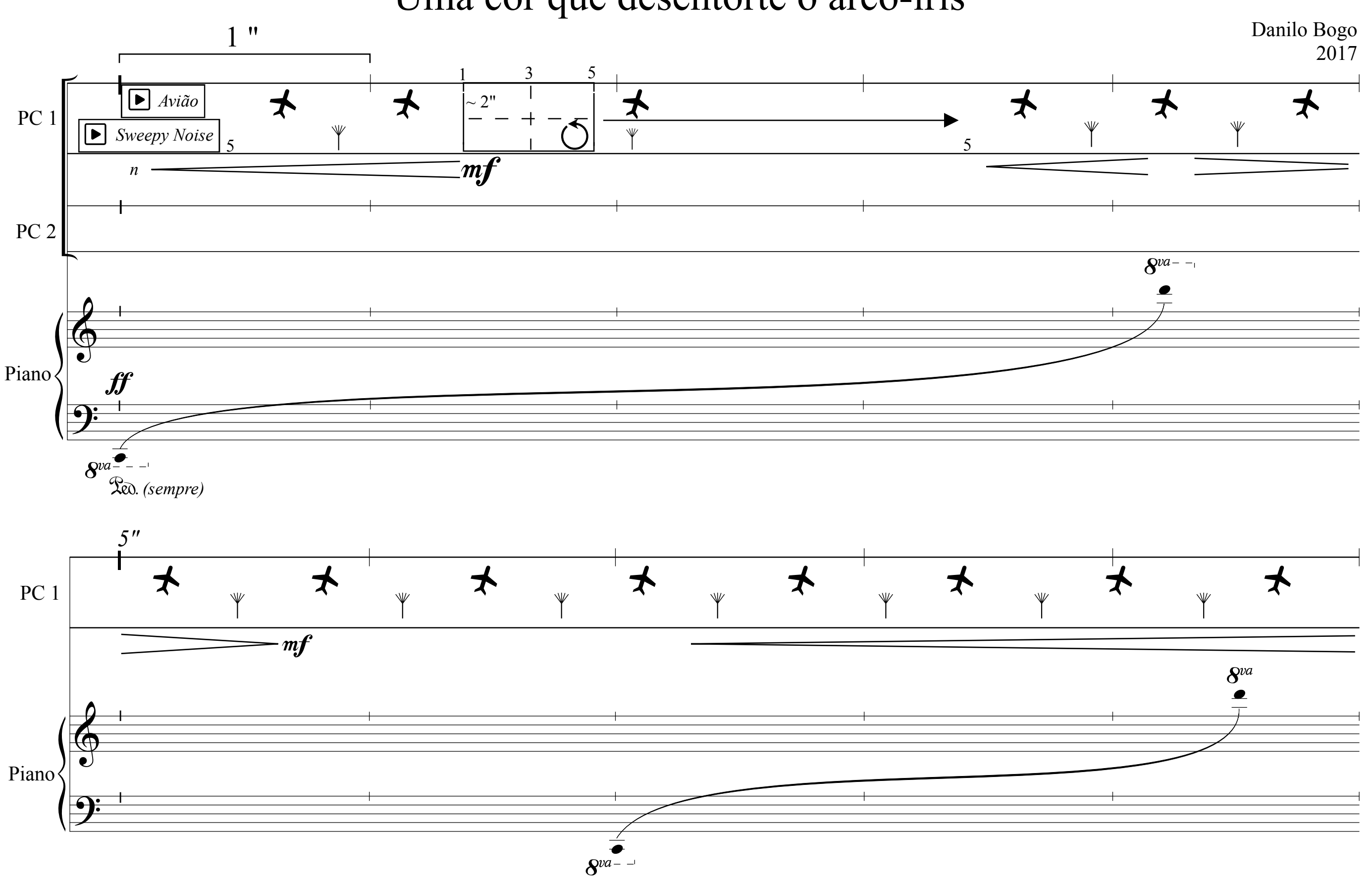



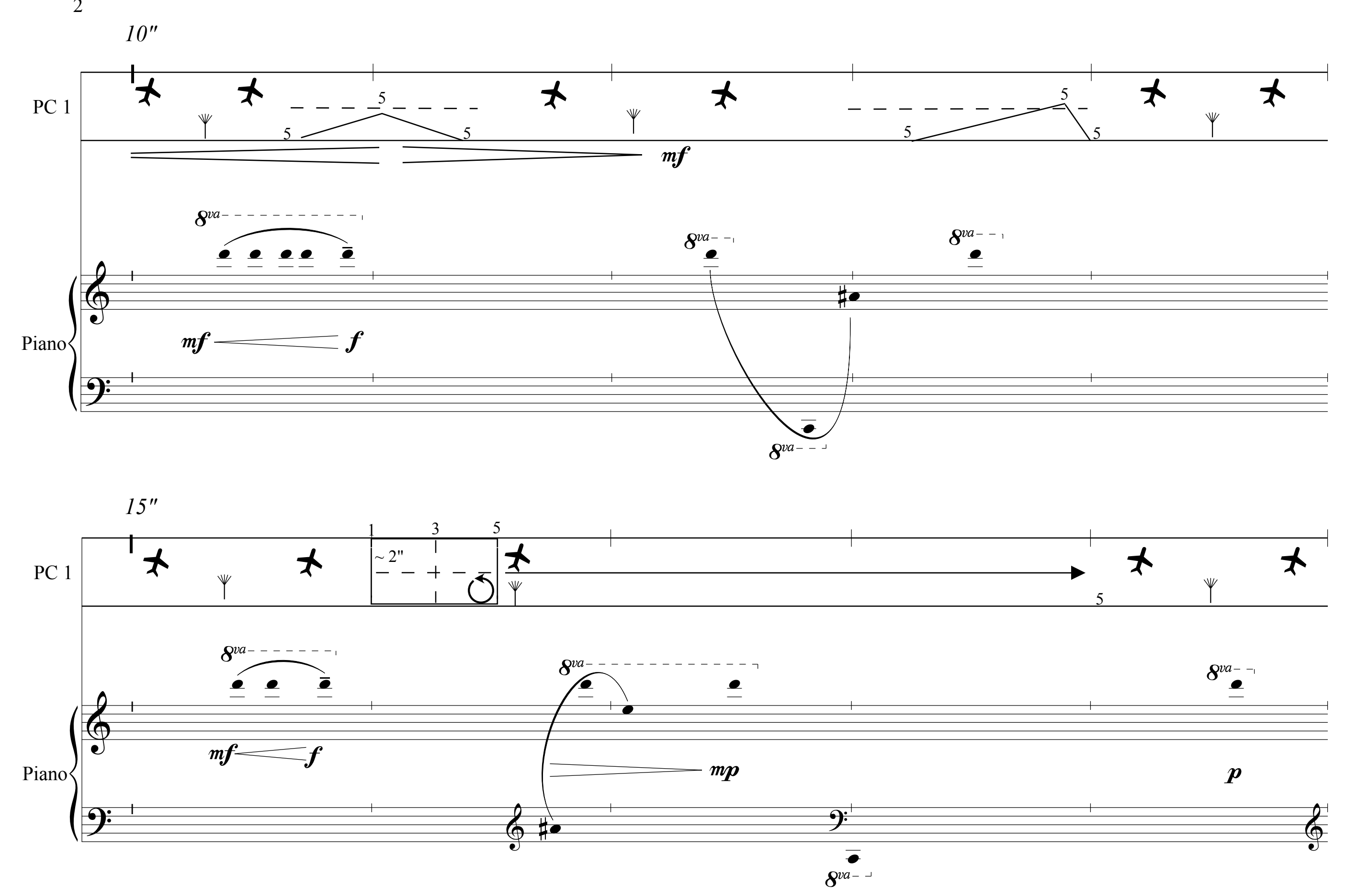


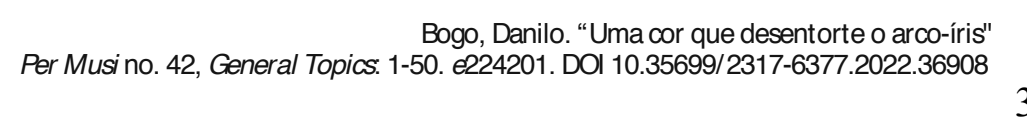
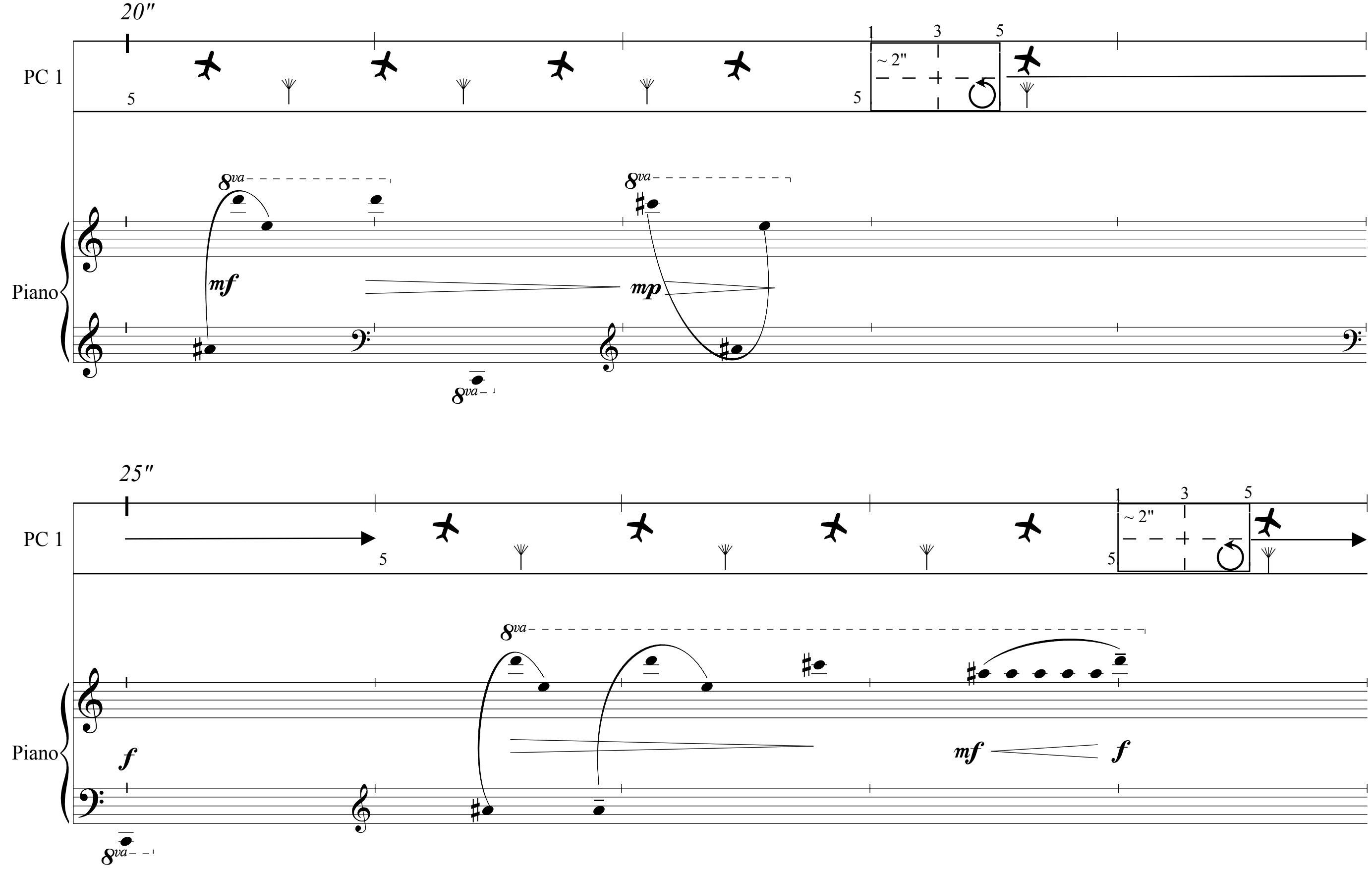
Bogo, Danilo. "Uma cor que desentorte o arco-íris"

4

Per Musi no. 42, General Topics. 1-50. e224201. DOl 10.35699/2317-6377.2022.36908
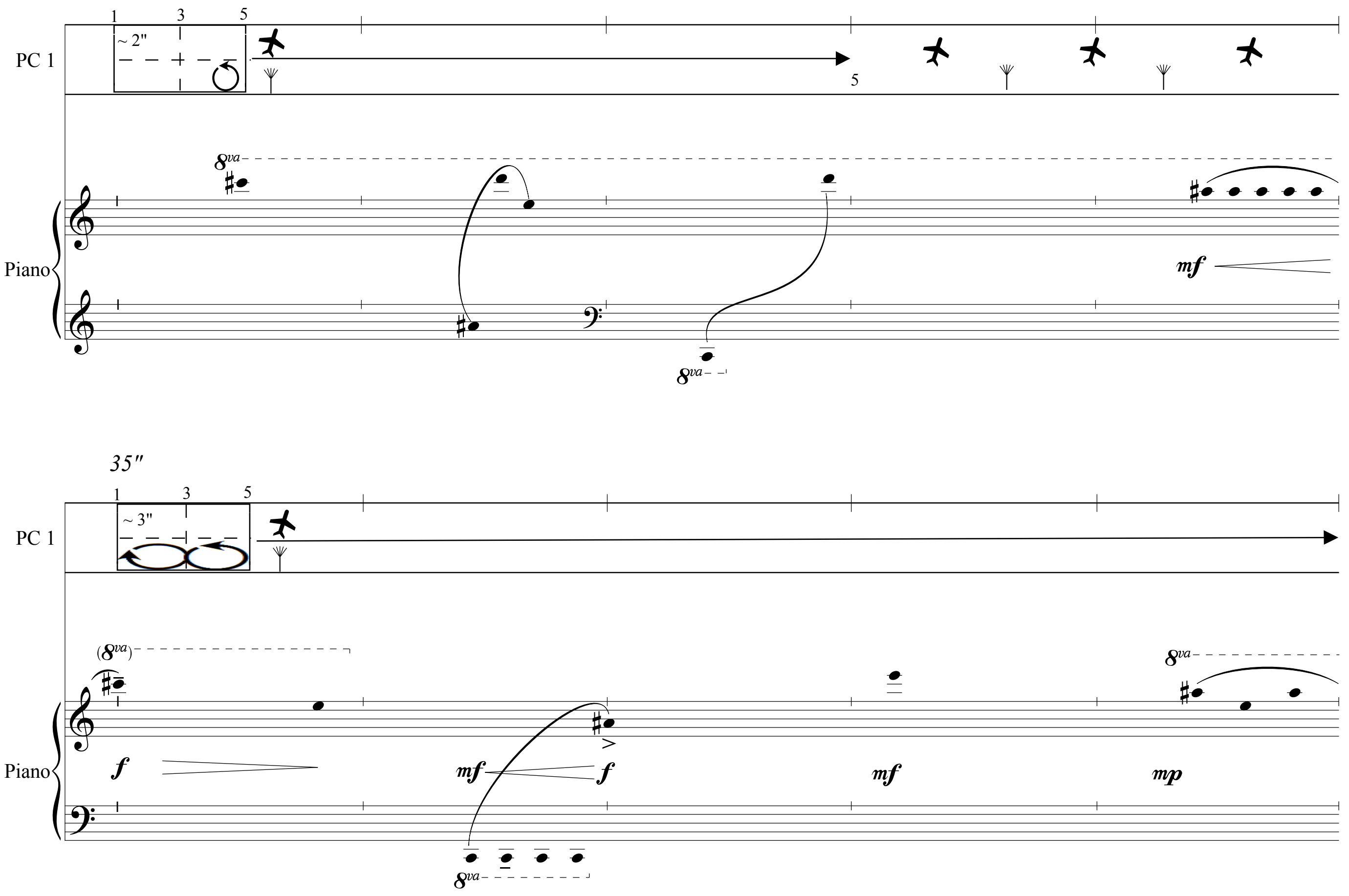


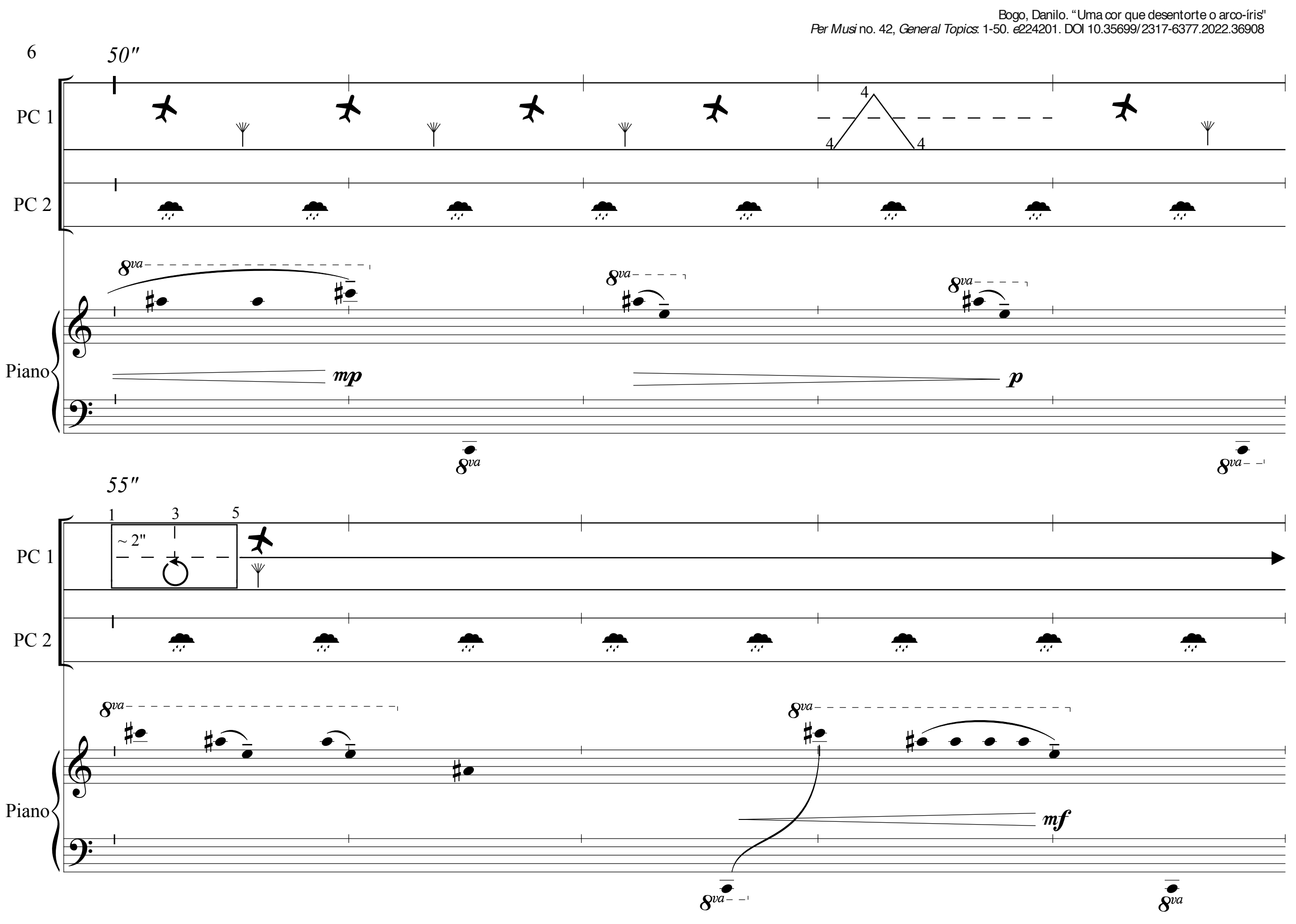


Bogo, Danilo. "Uma cor que desentorte o arco-íris"

$60^{\prime \prime}$

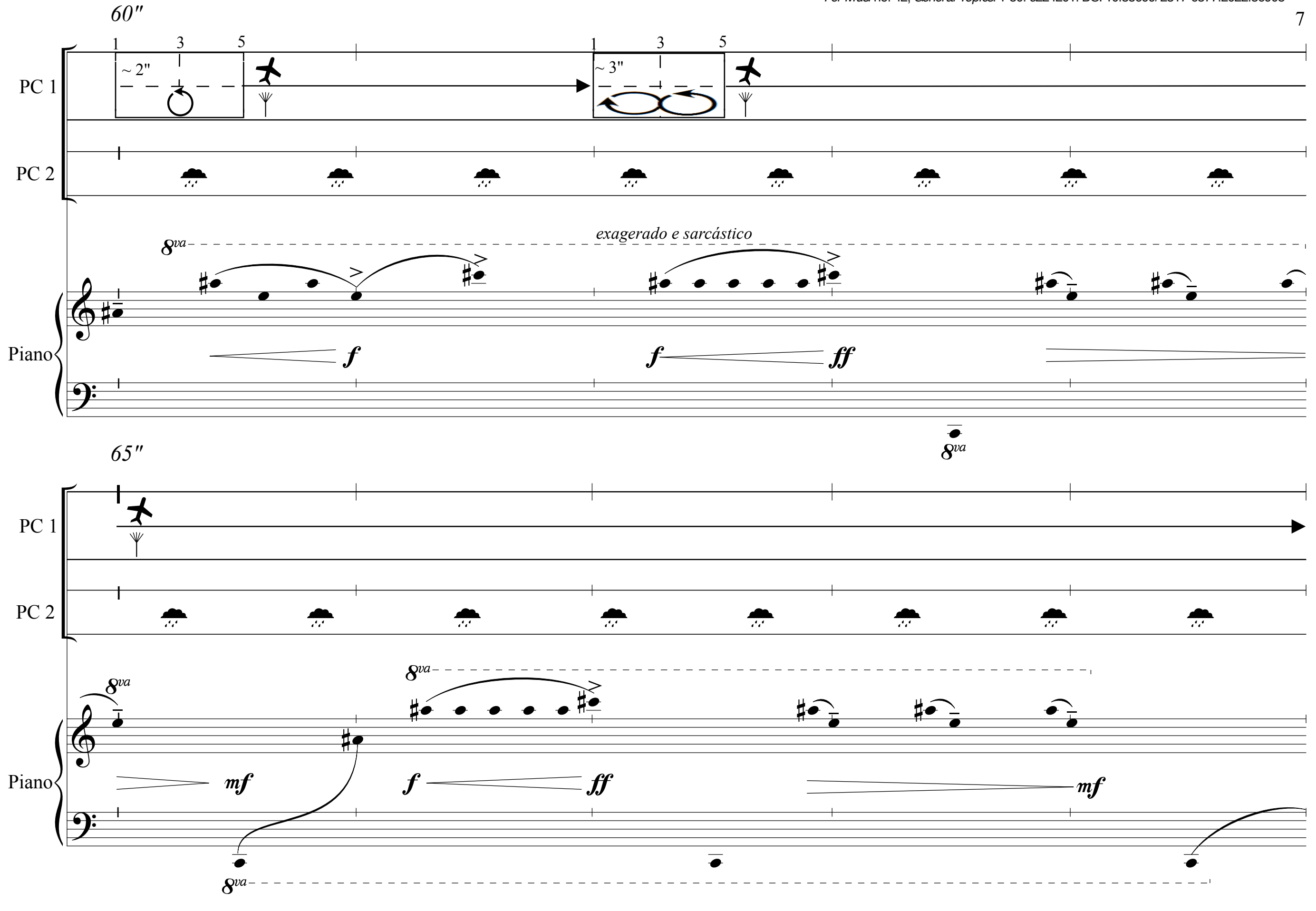


Bogo, Danilo. "Uma cor que desentorte o arco-íris"
Per Musi no. 42, General Topics. 1-50. e224201. DOl 10.35699/2317-6377.

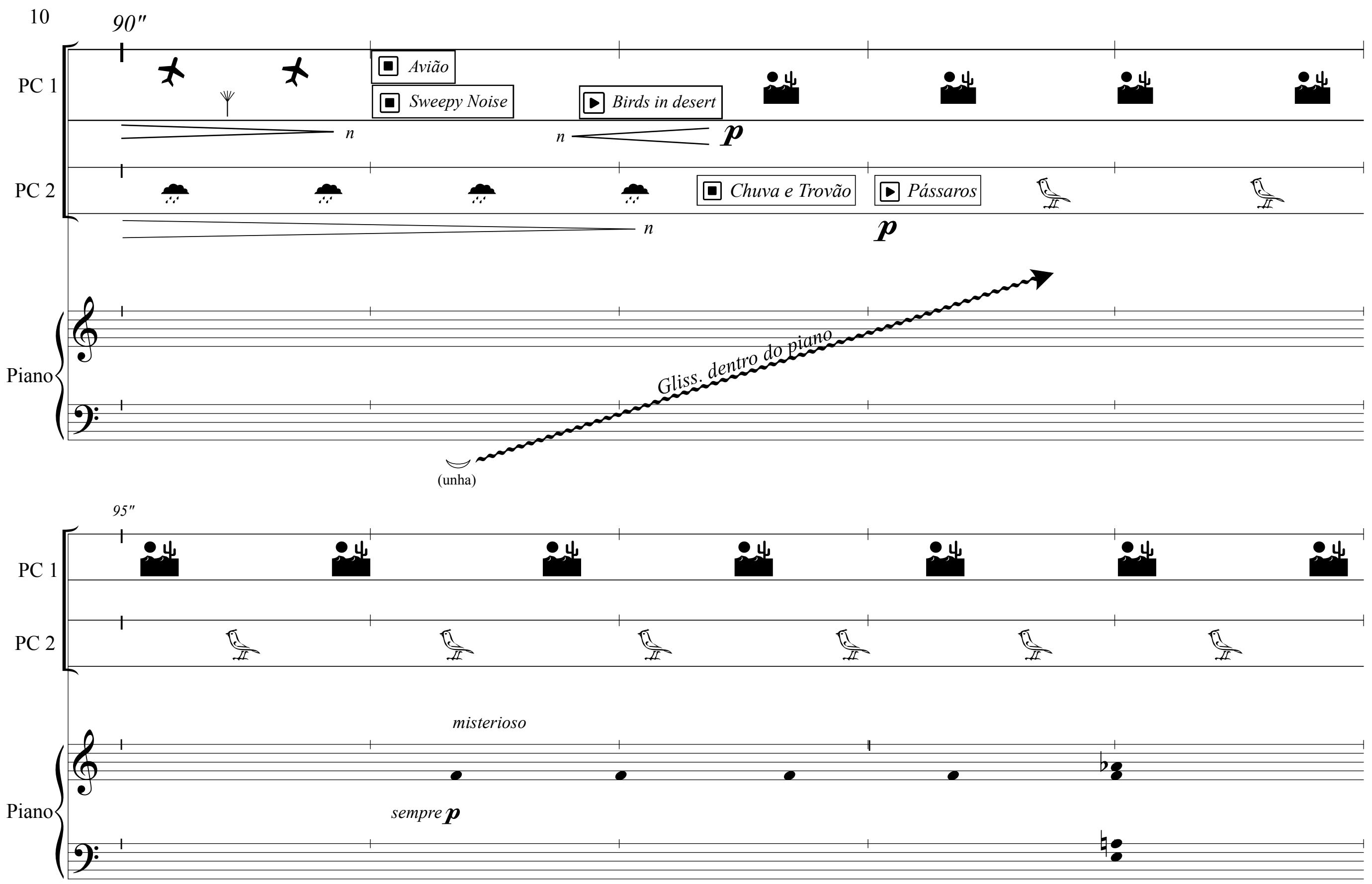


Per Musi no. 42, General Topics 1-50, Danilo. "Uma cor que desentorte o arco-íris"

11
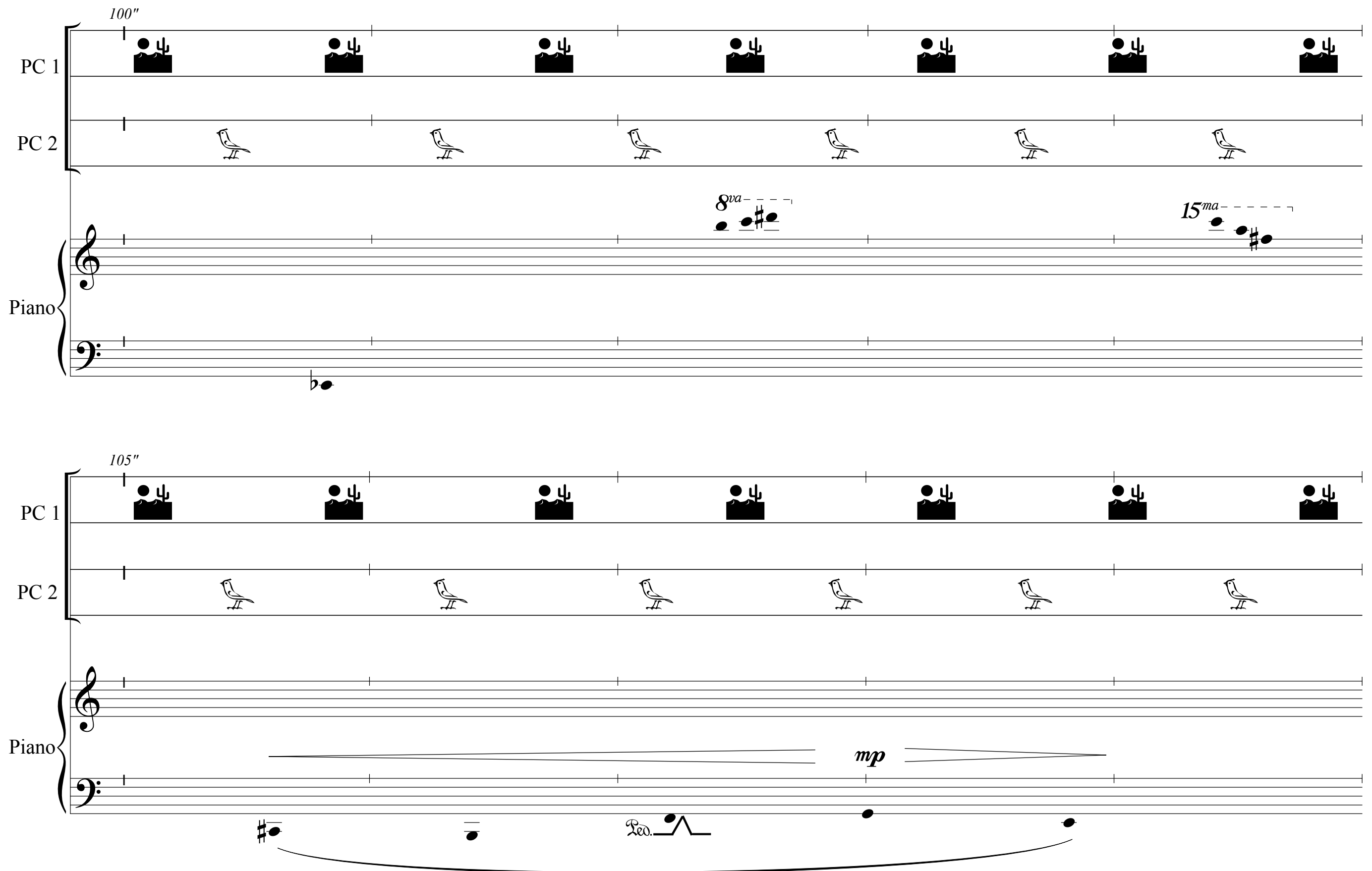

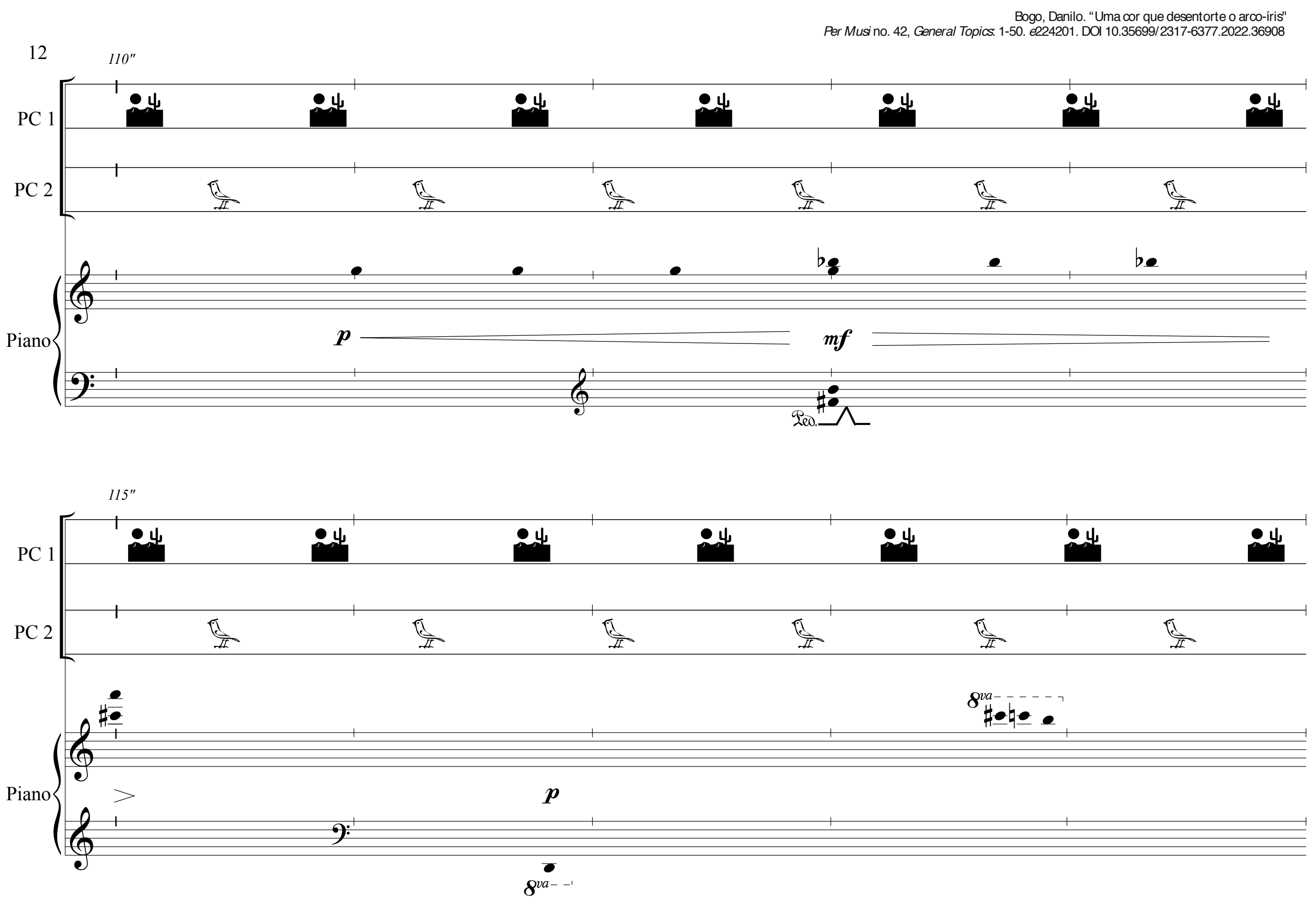
Bogo, Danilo. "Uma cor que desentorte o arco-íris"

Per Musi no. 42, General Topics. 1-50. e224201. DOl 10.35699/2317-6377.2022.36908

13
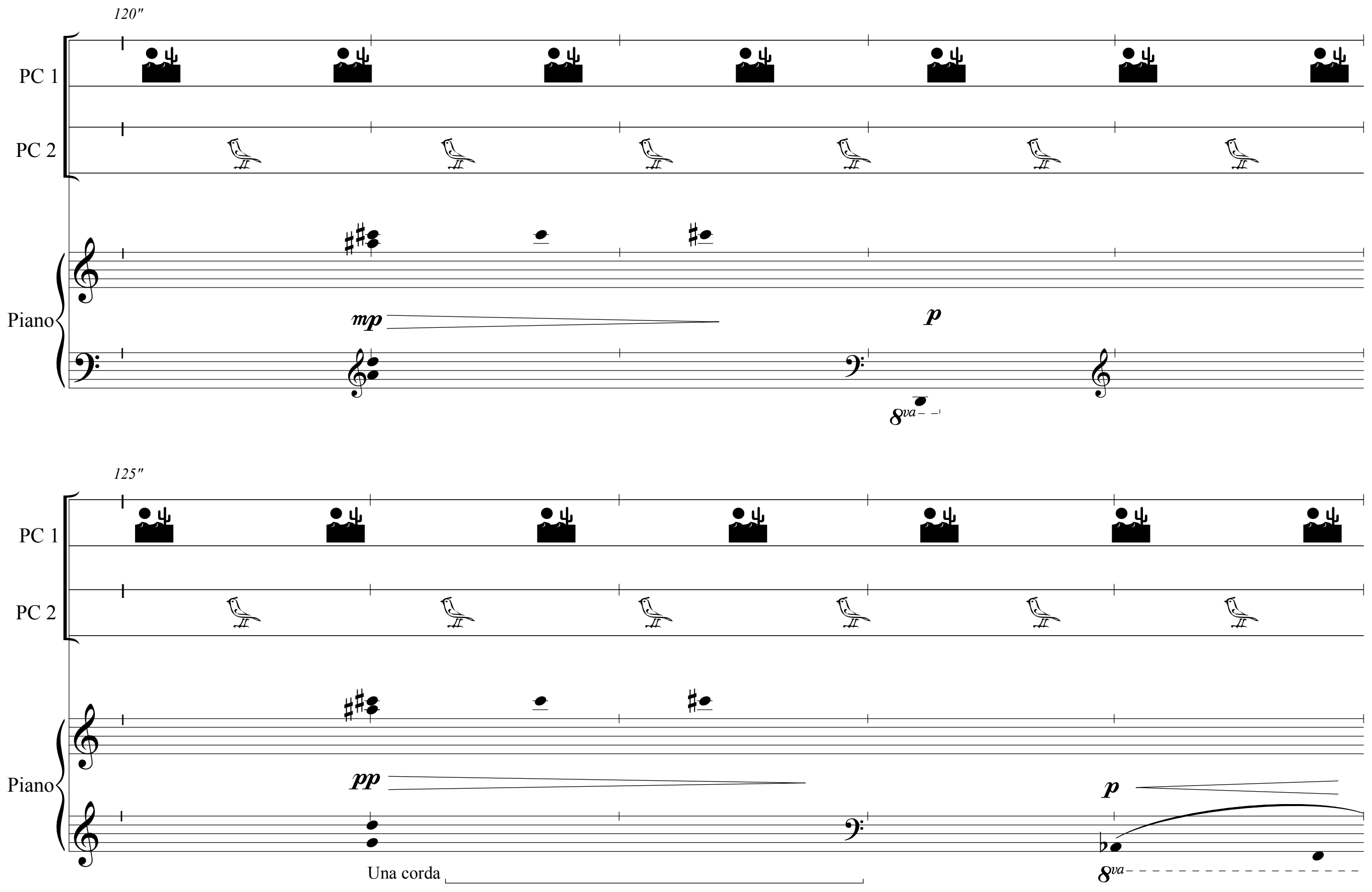

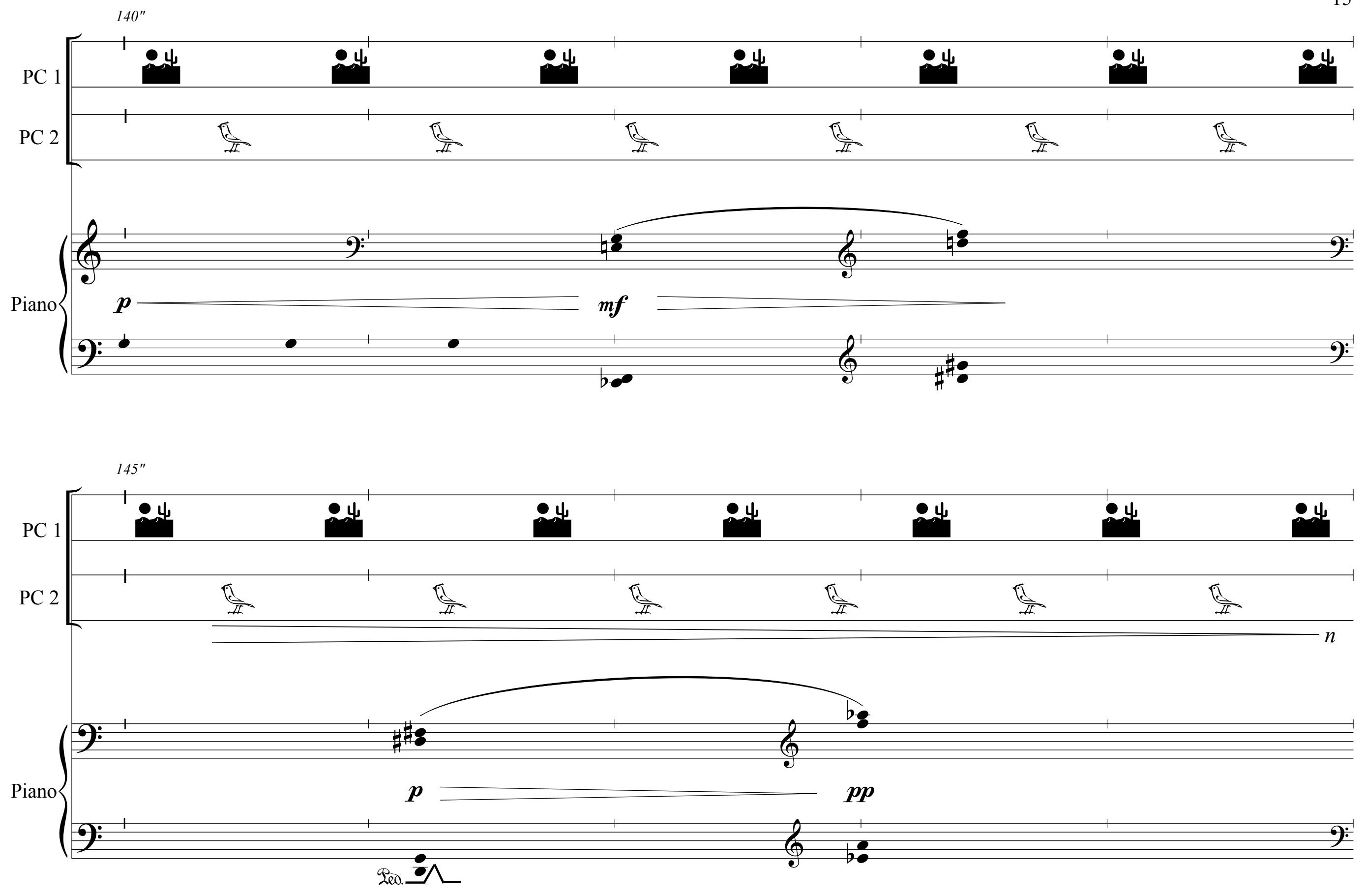

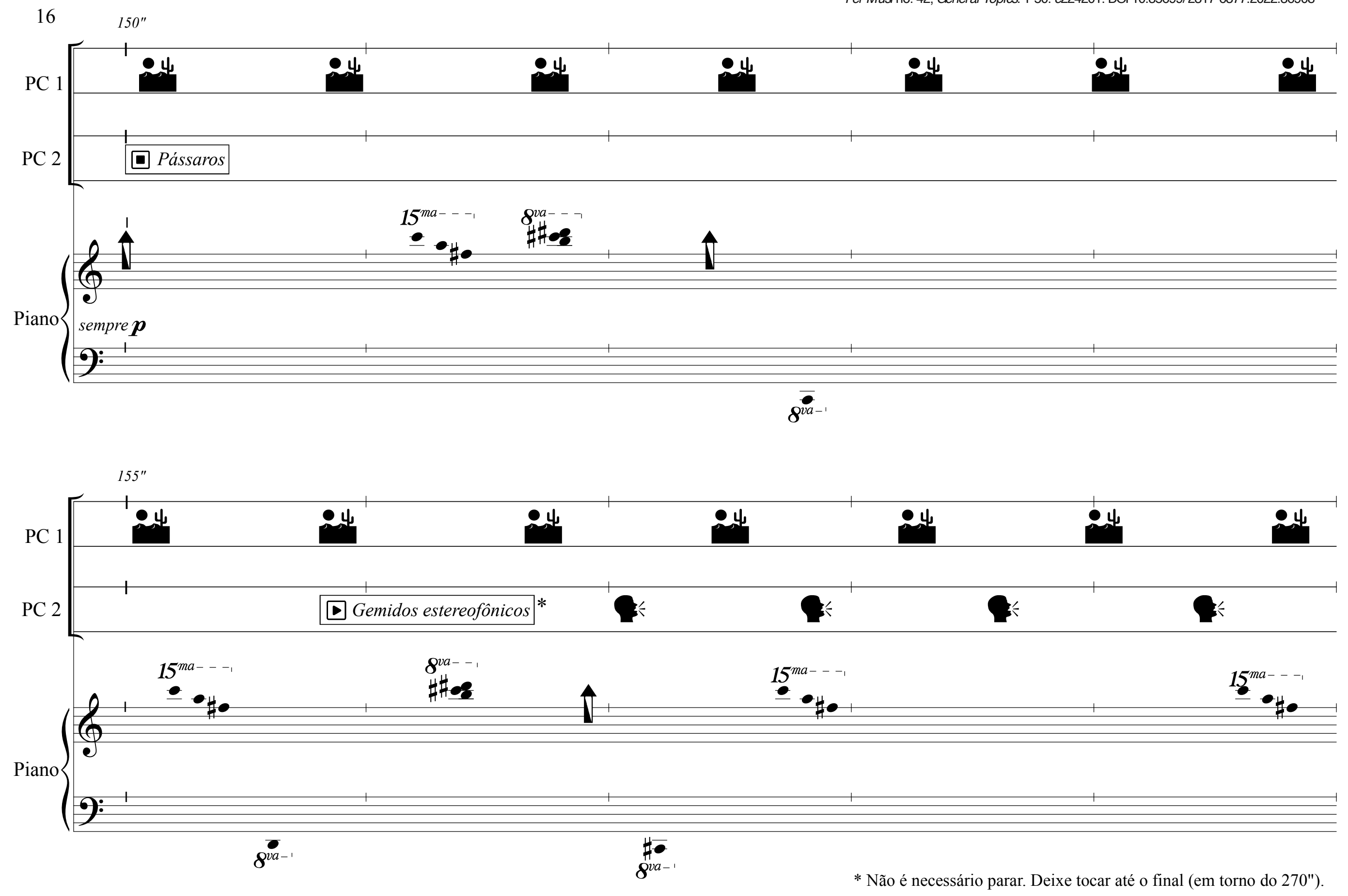

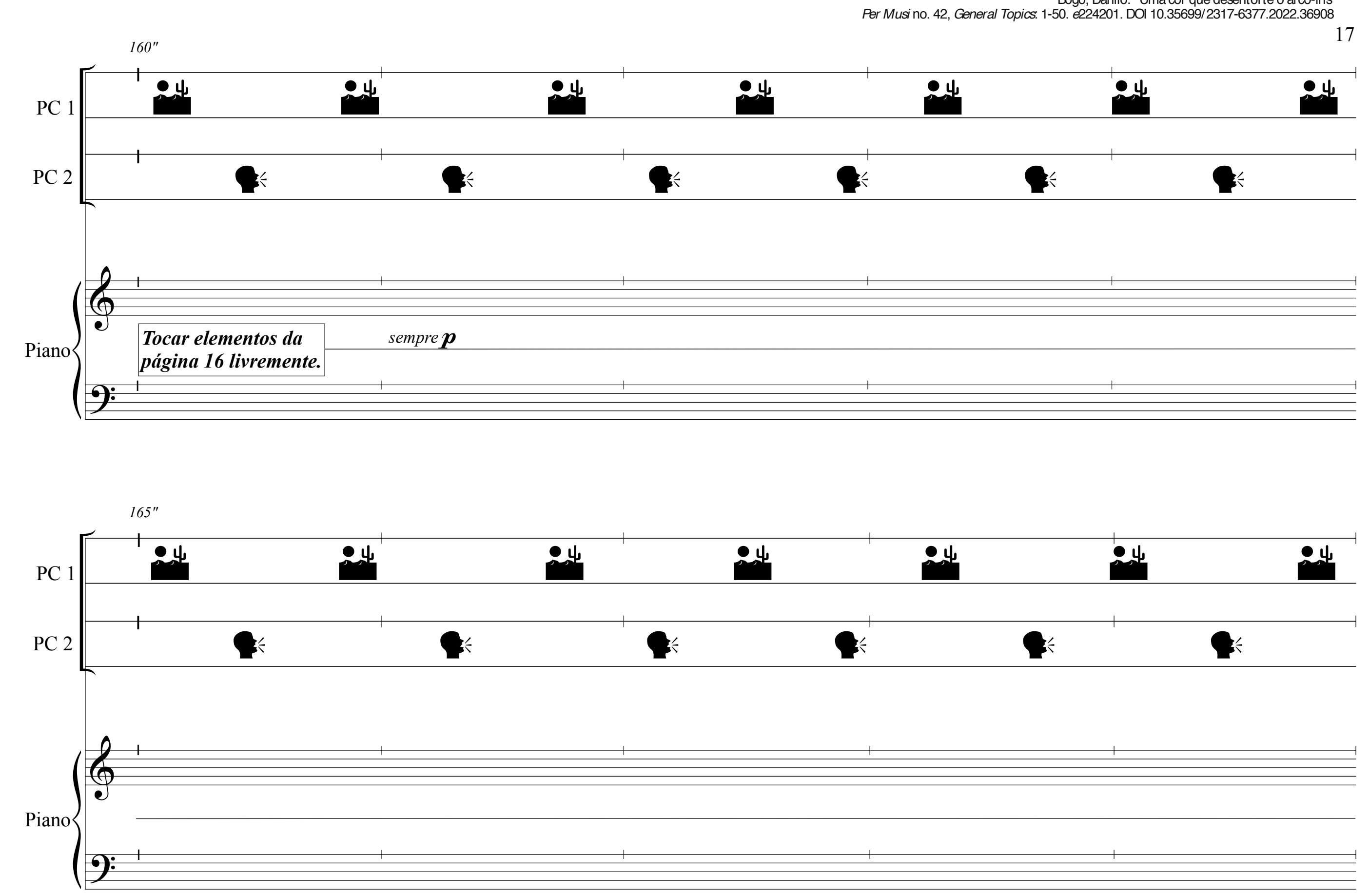

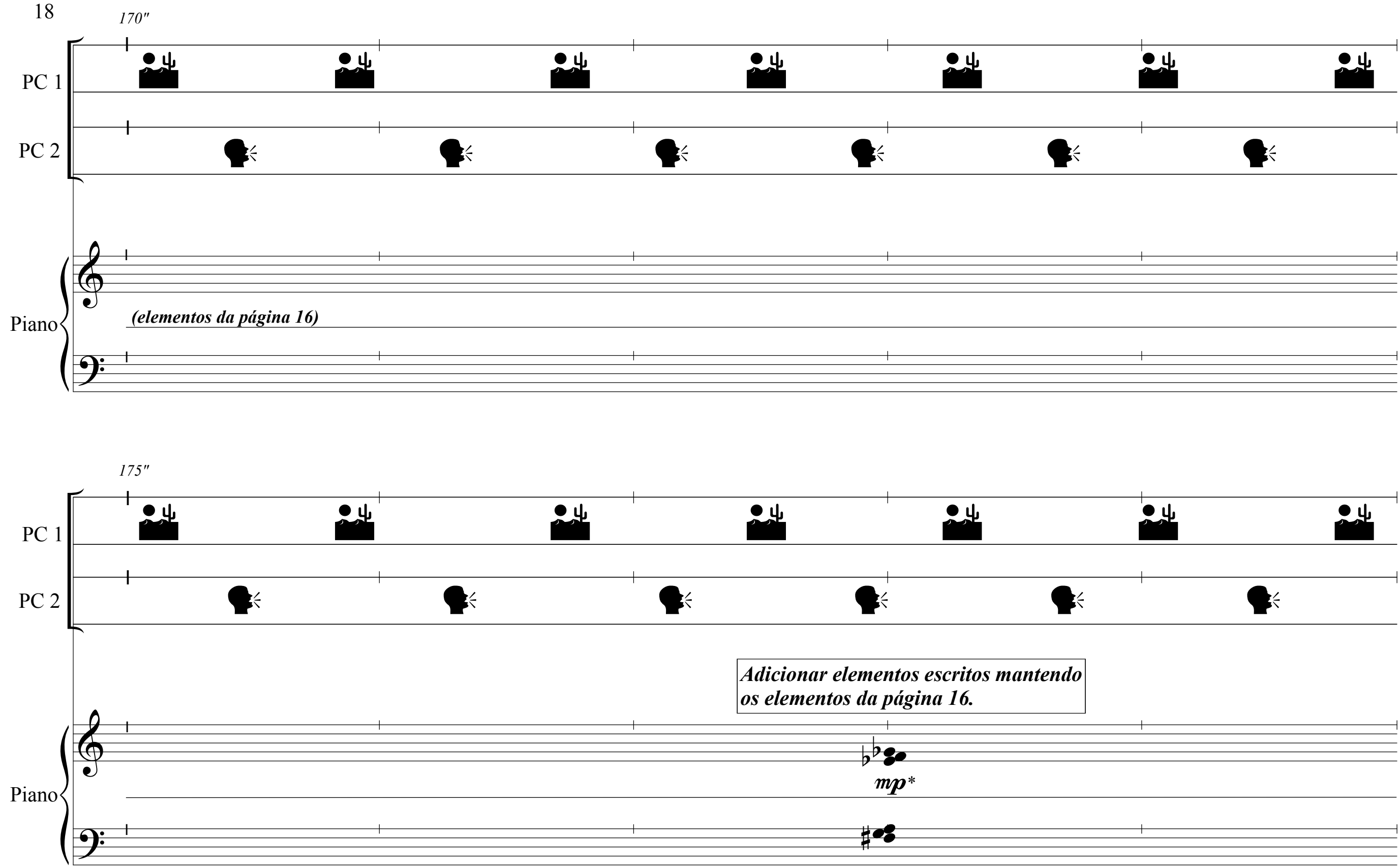

* Dinâmica válida apenas para elementos escritos. Os elementos da pag. 16 continuam sempre $\boldsymbol{p}$ 

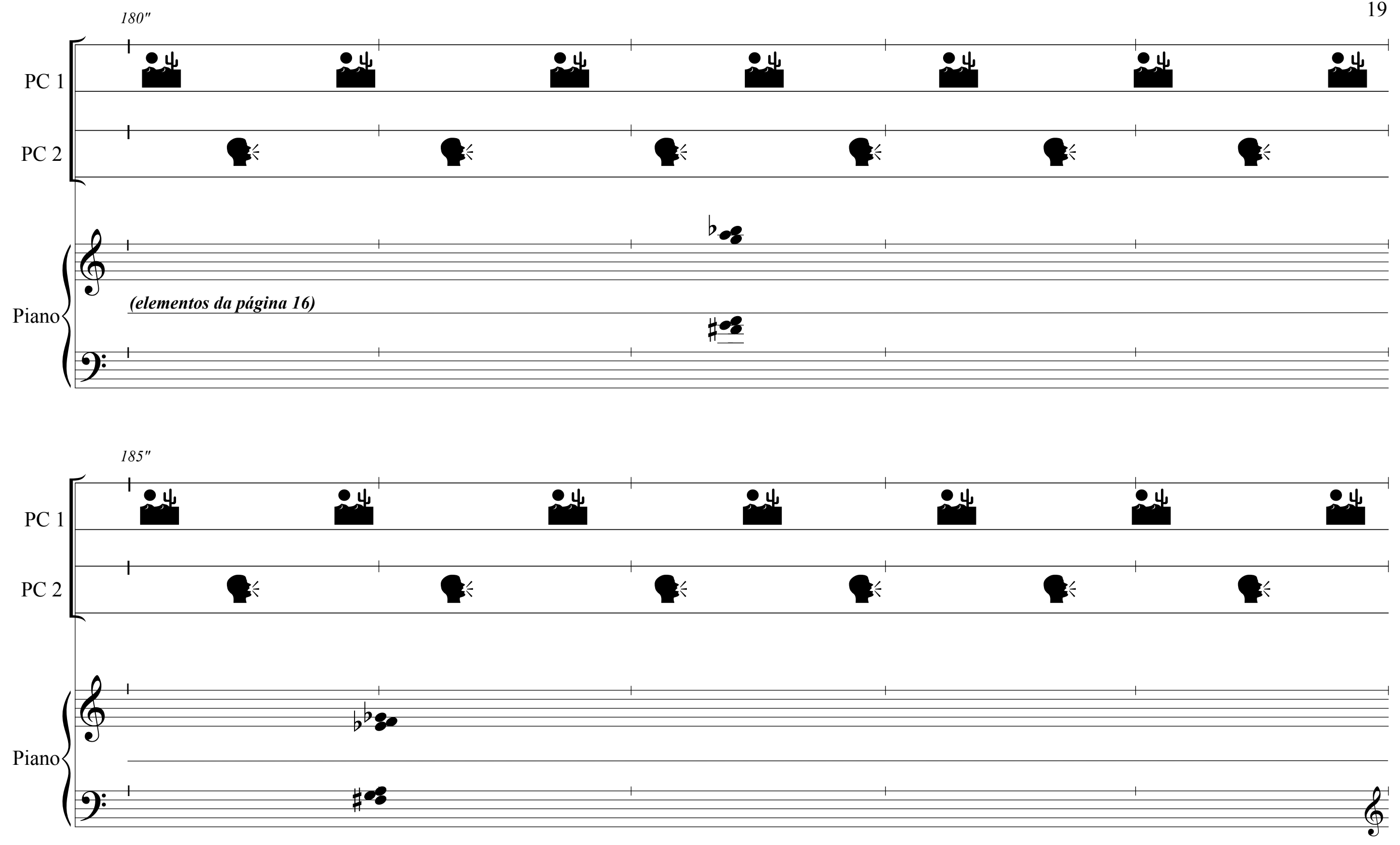


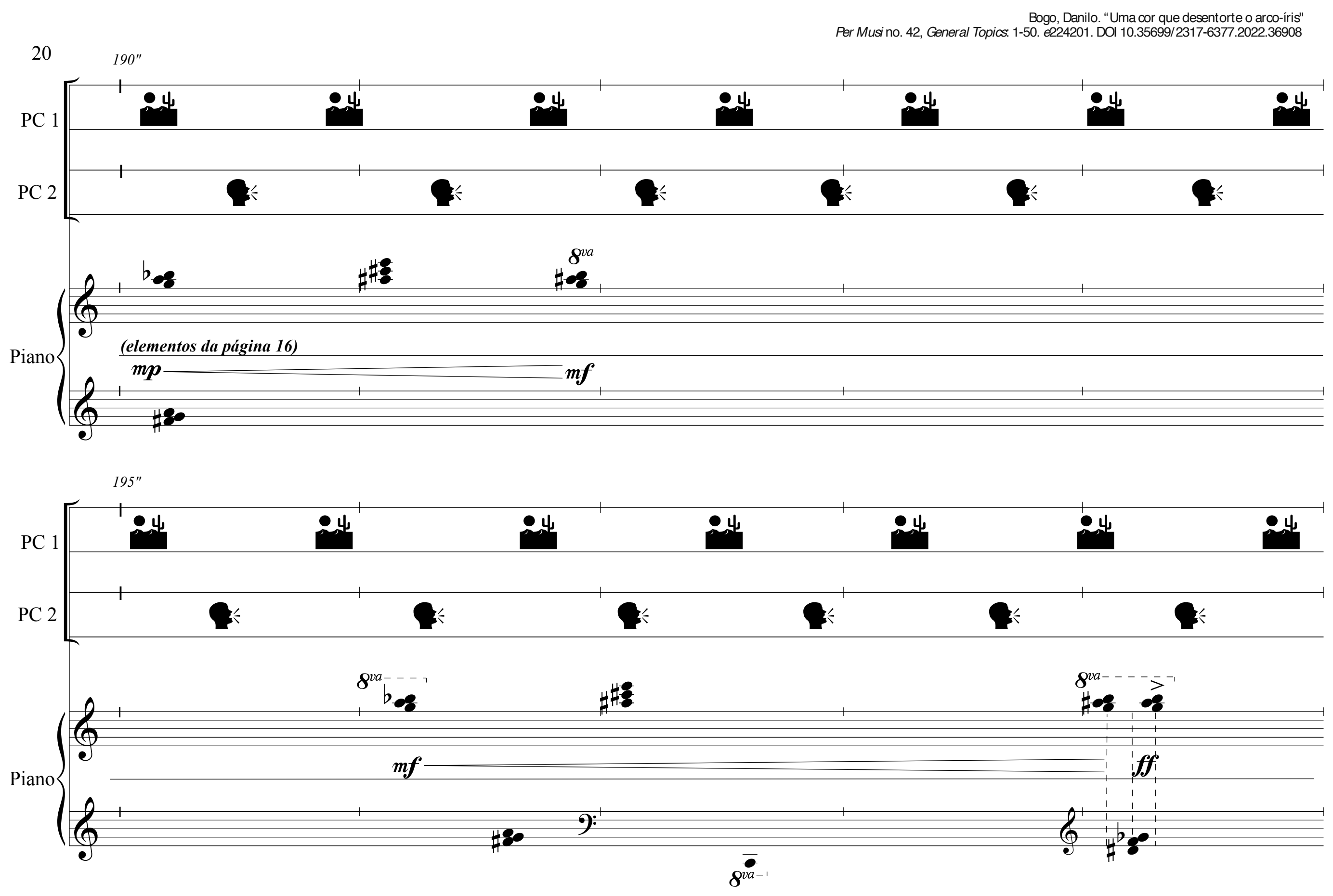




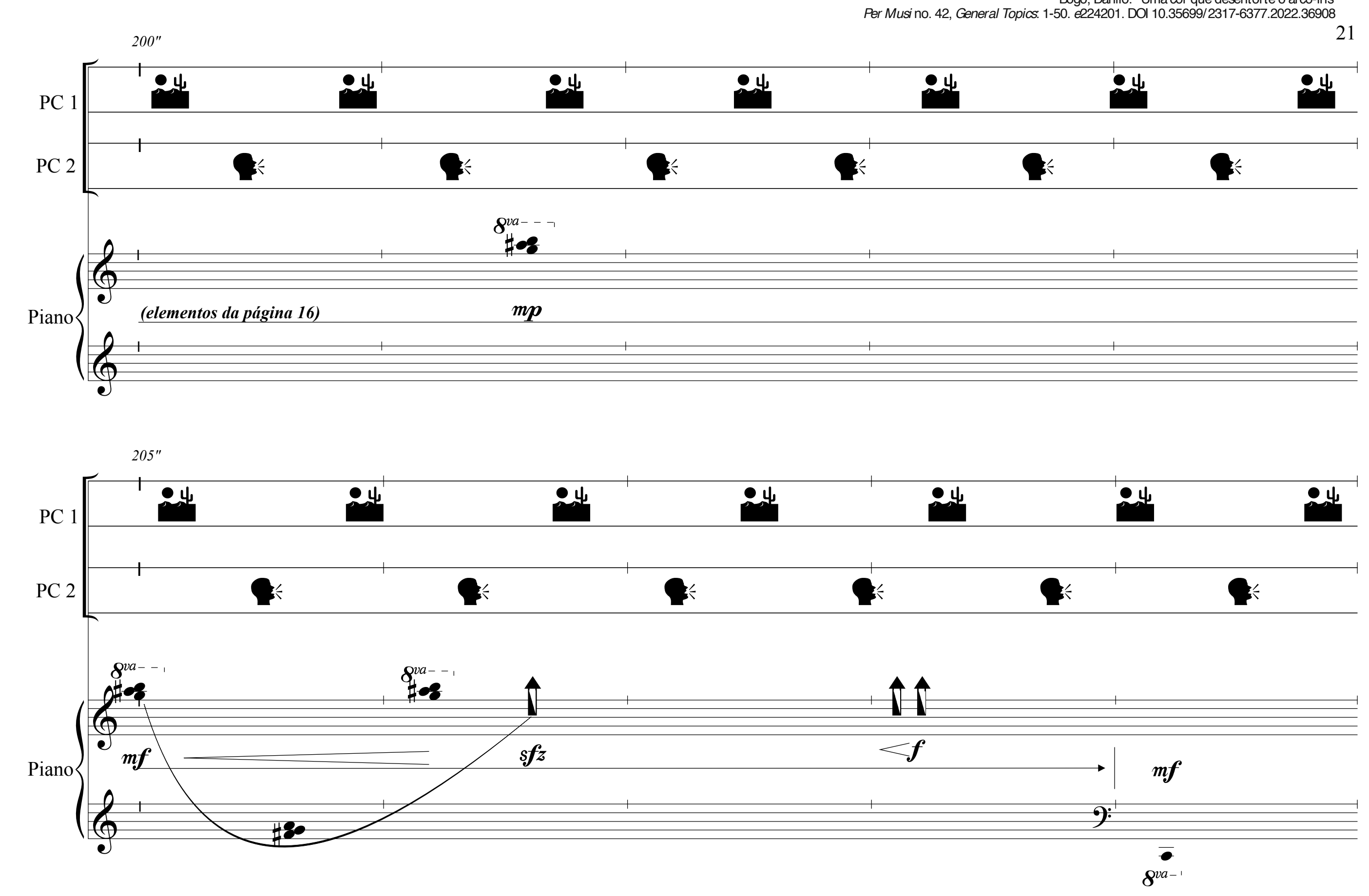



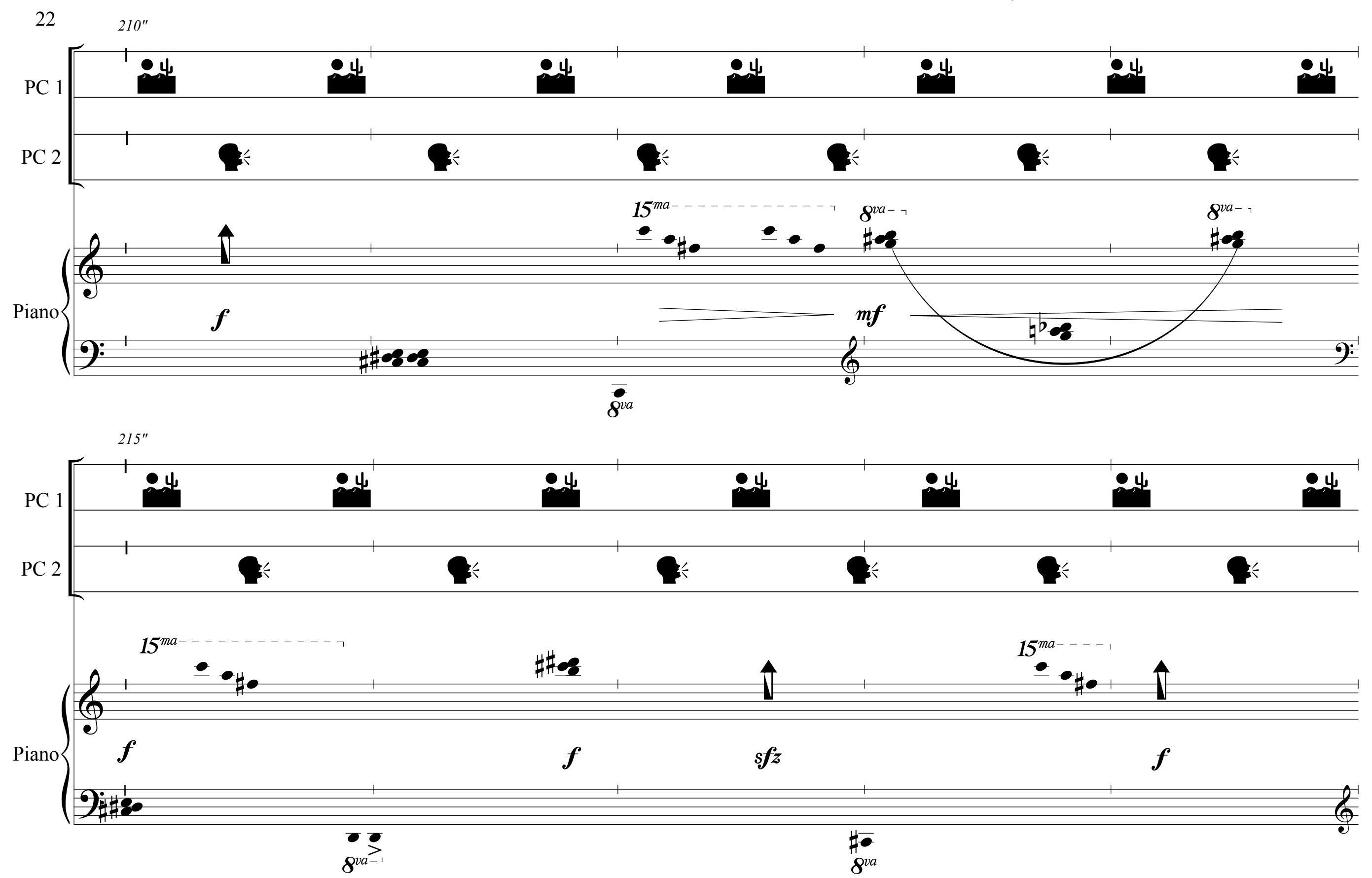

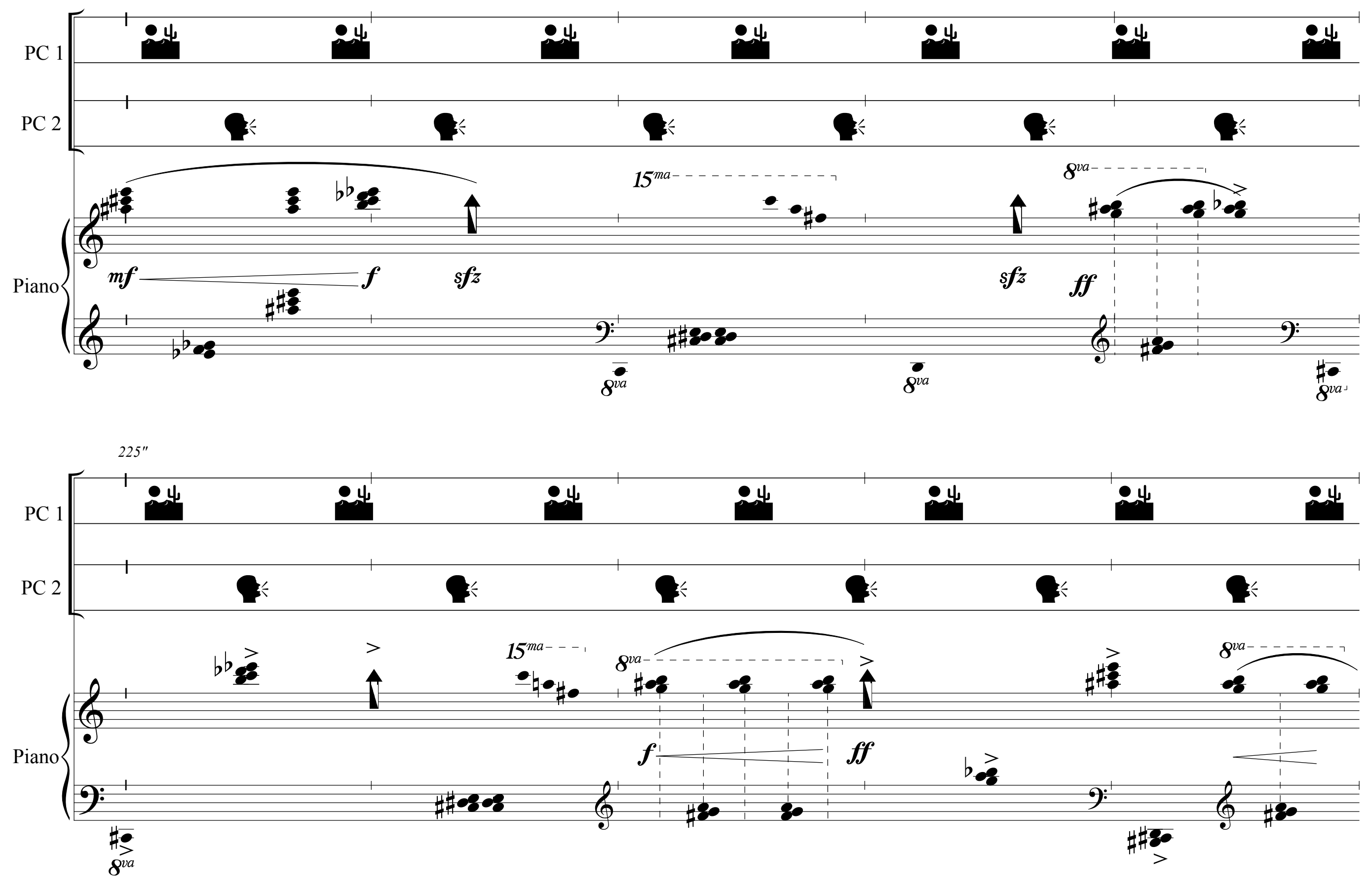

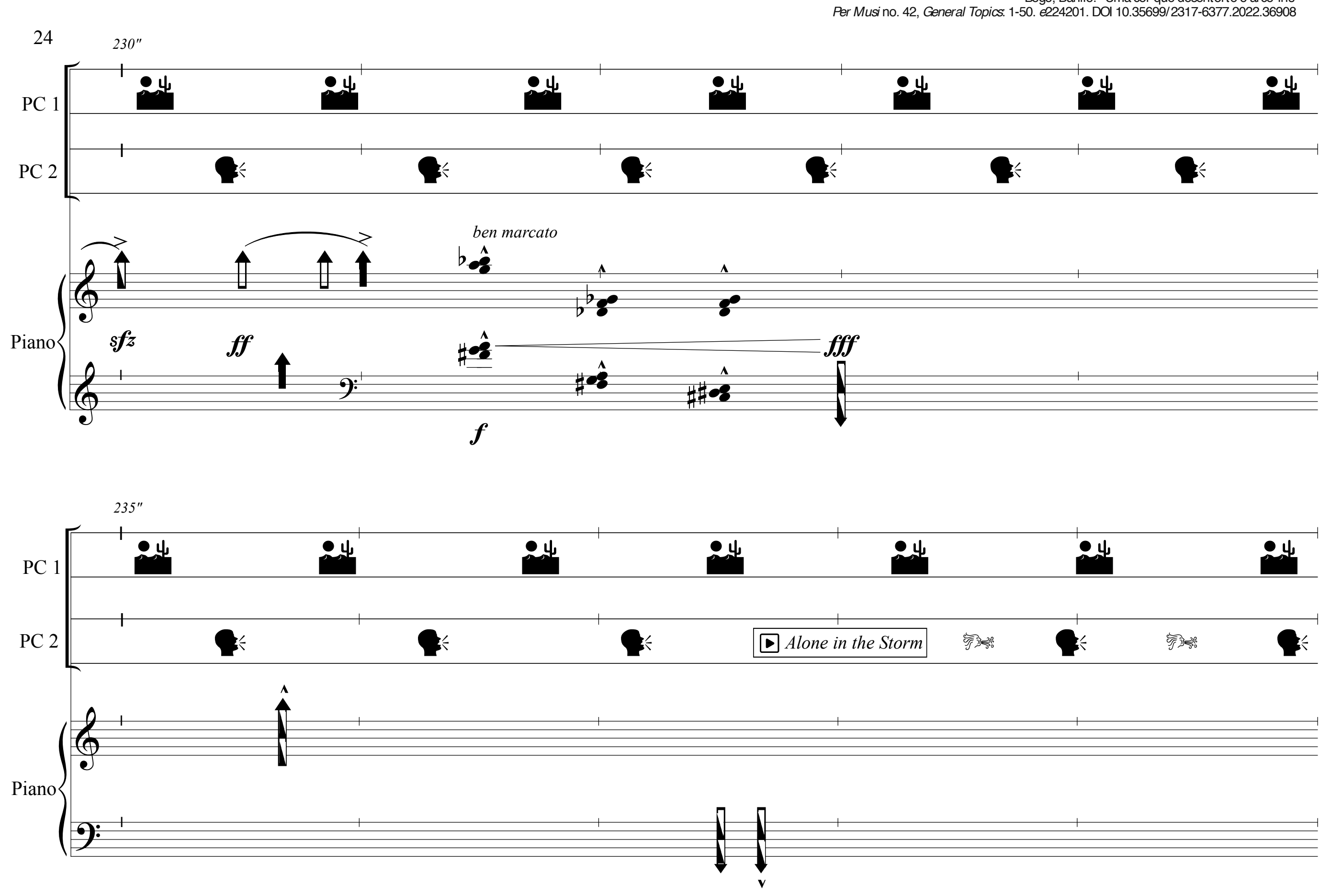

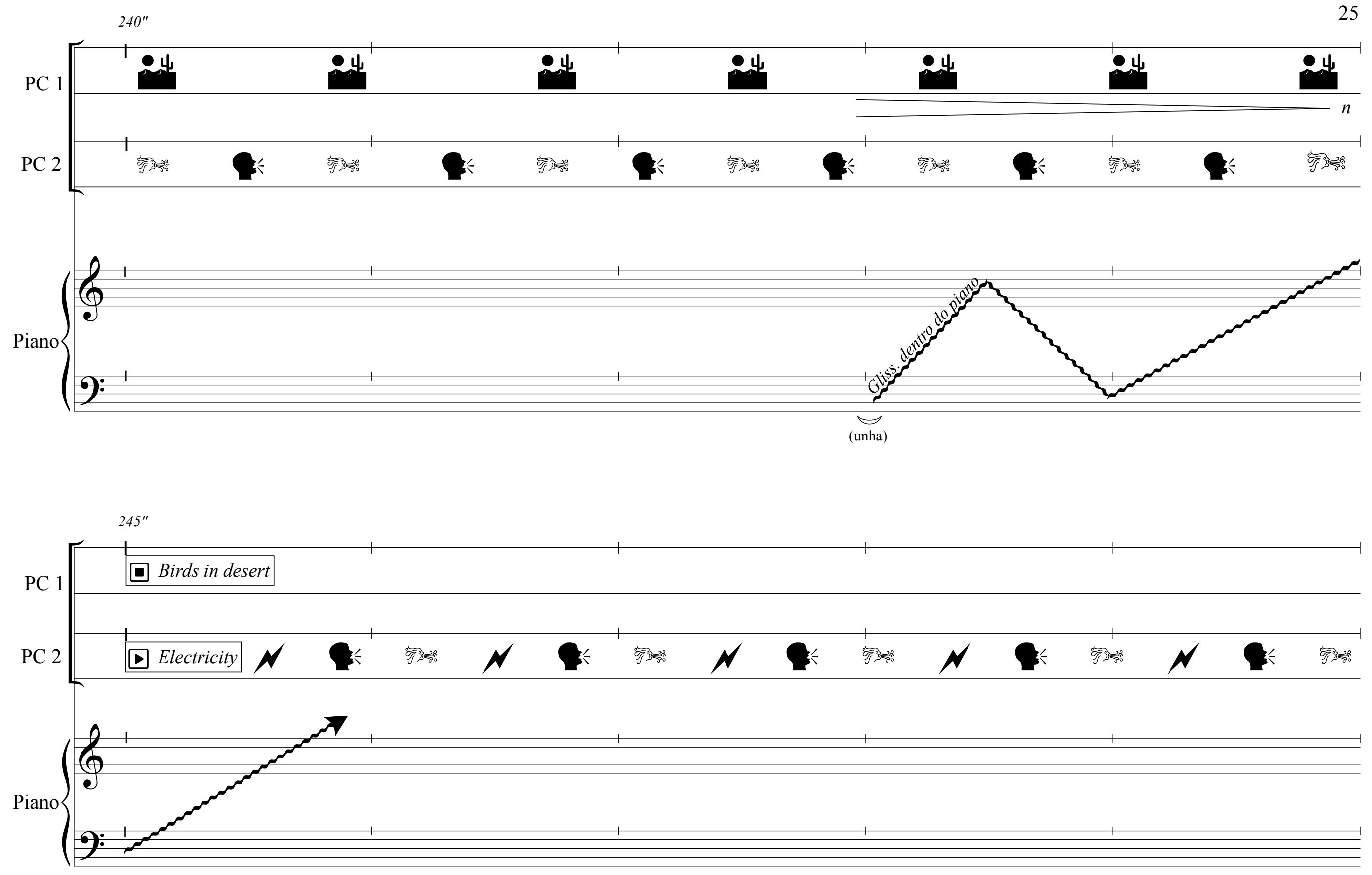


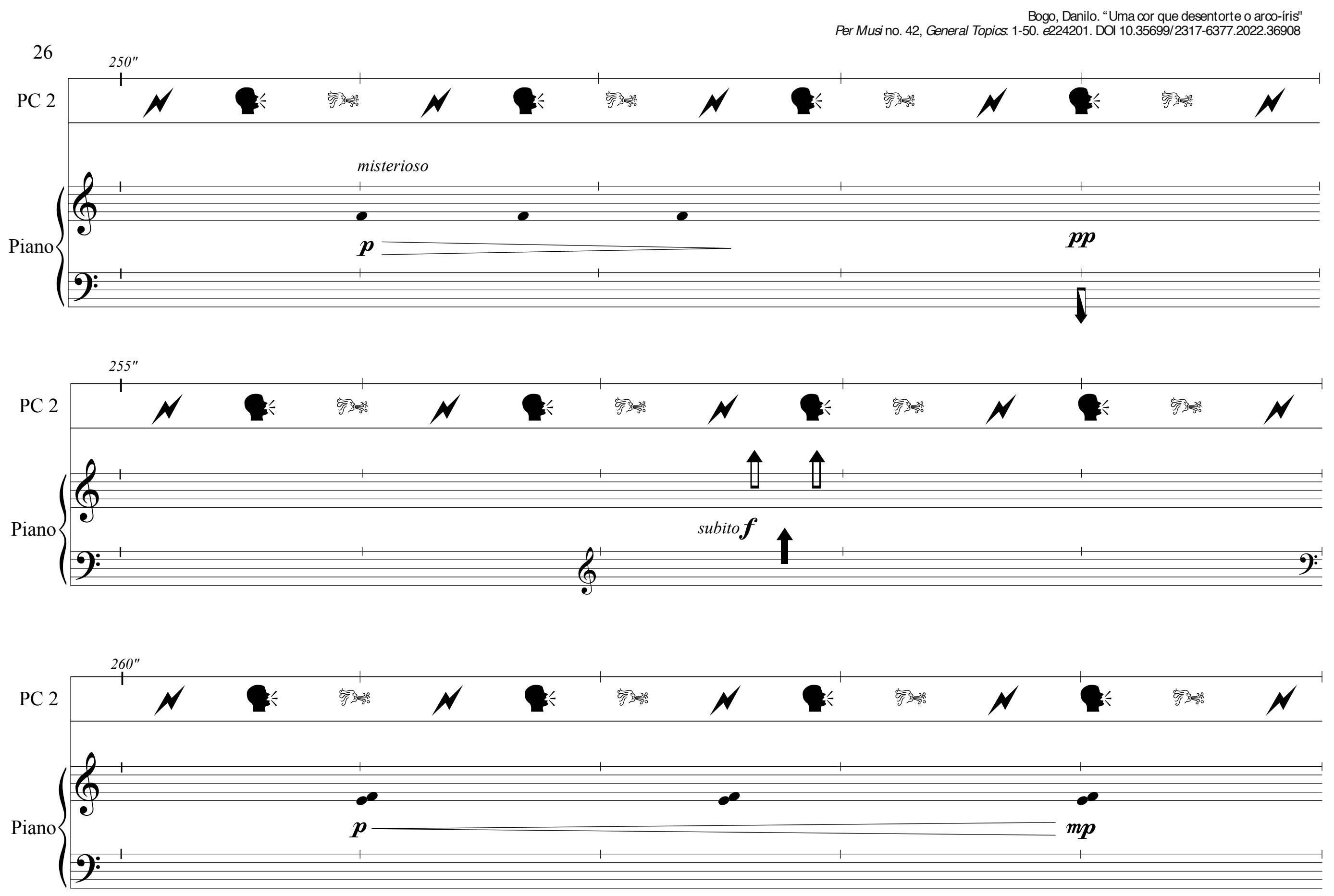



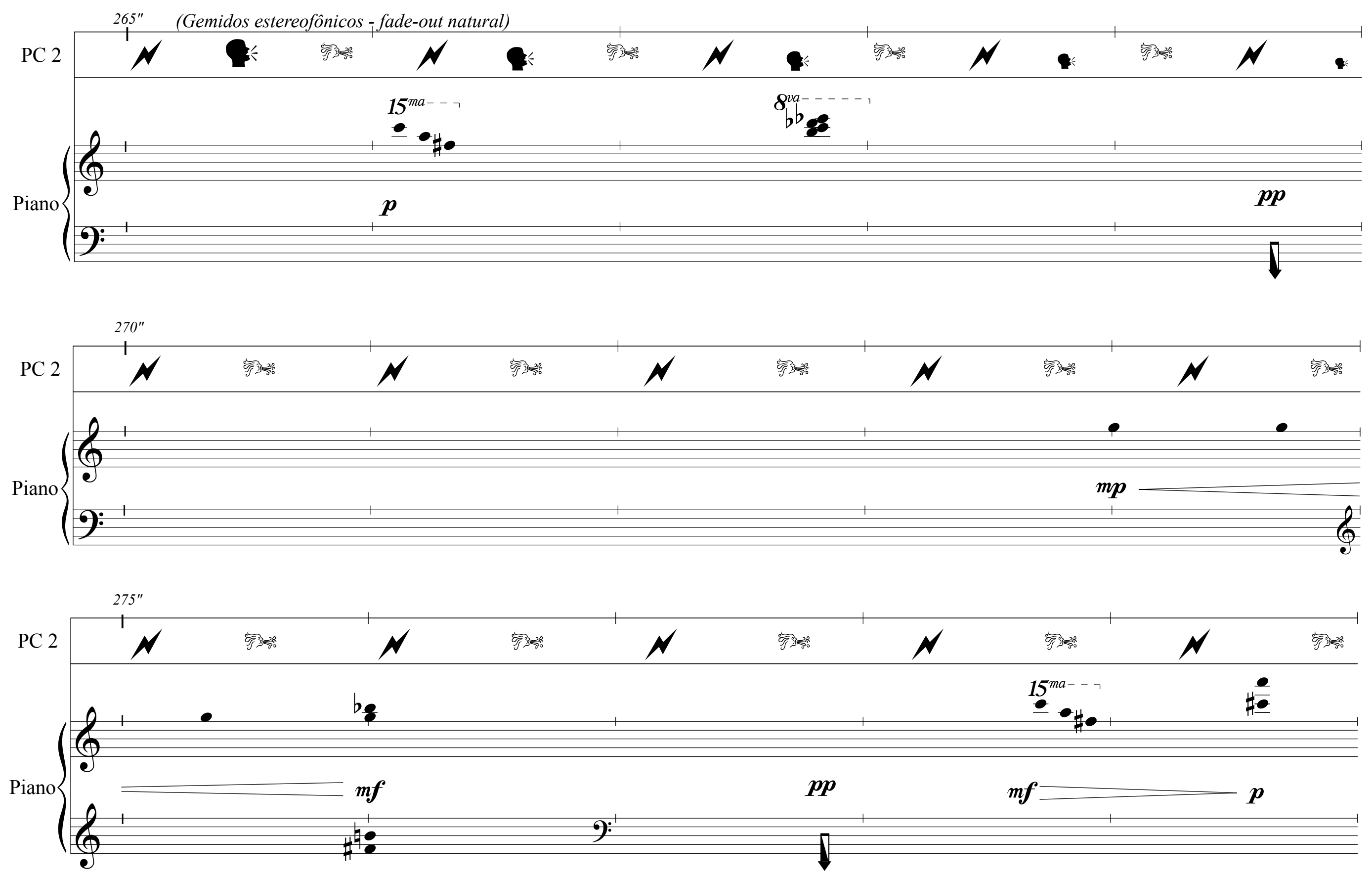

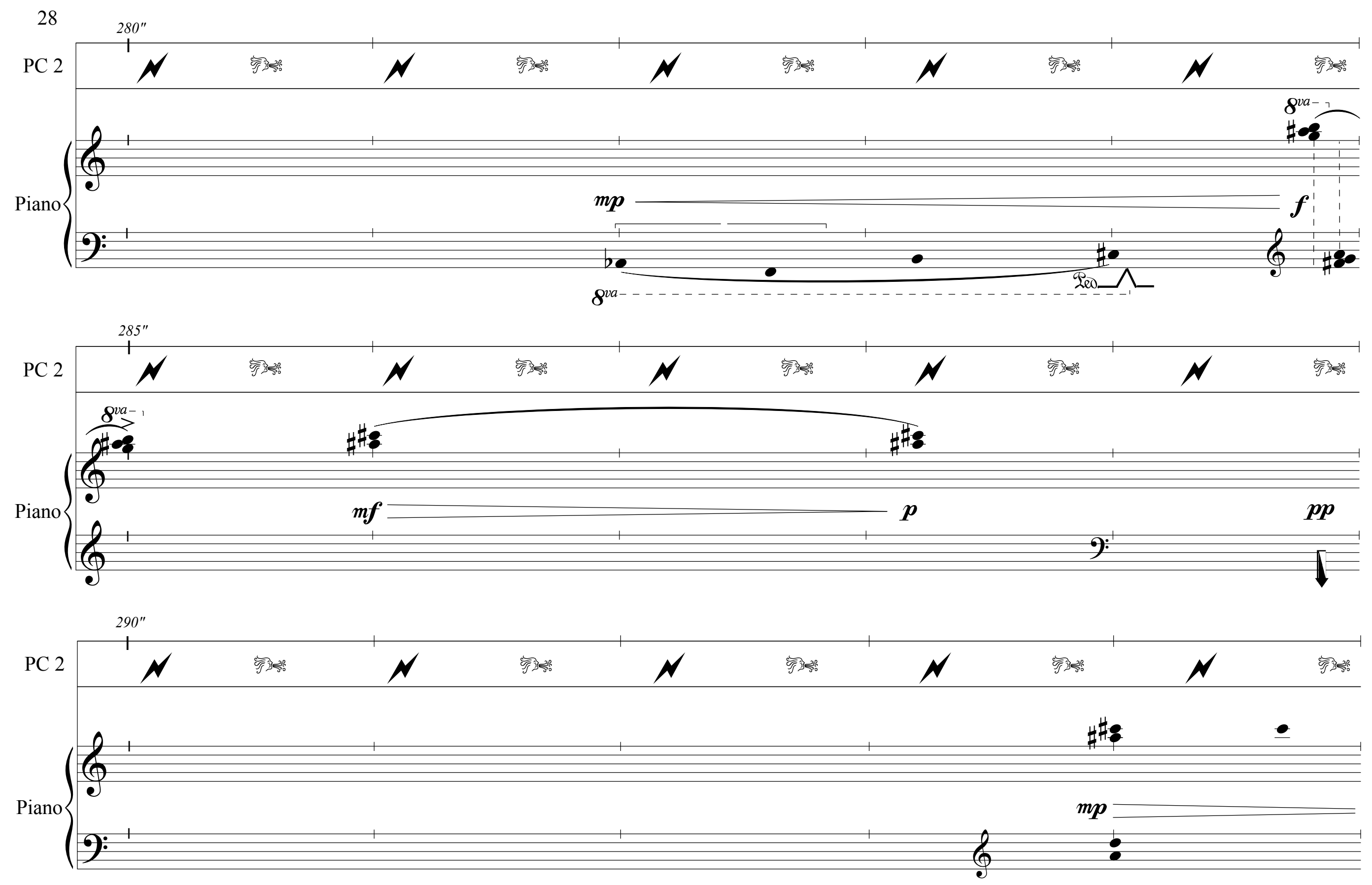
Bogo, Danilo. "Uma cor que desentorte o arco-íris"
Per Musino. 42. General Topics. 1-50. e224201. DOl 10.35699/2317-6377.2022.36908

29
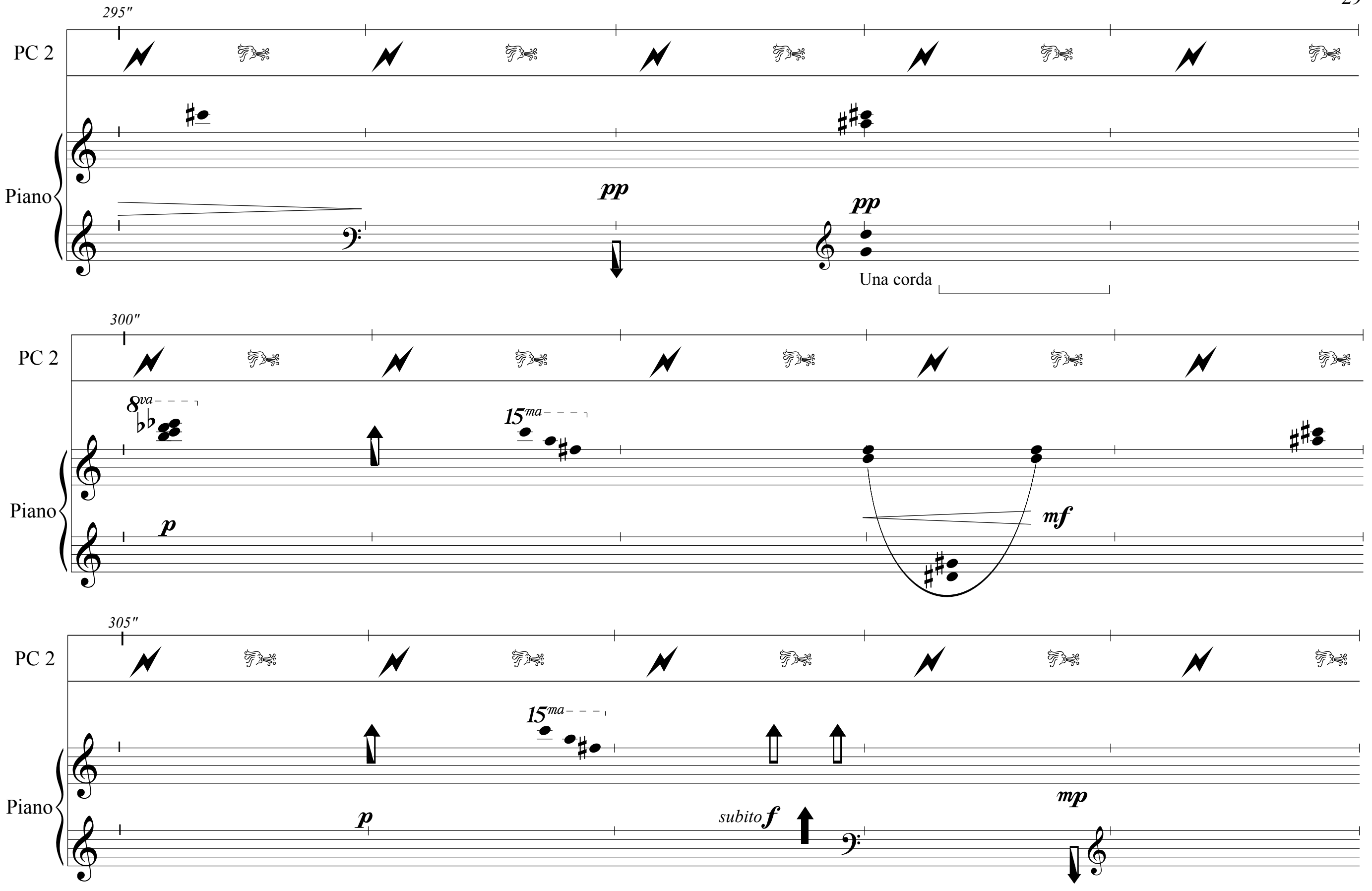

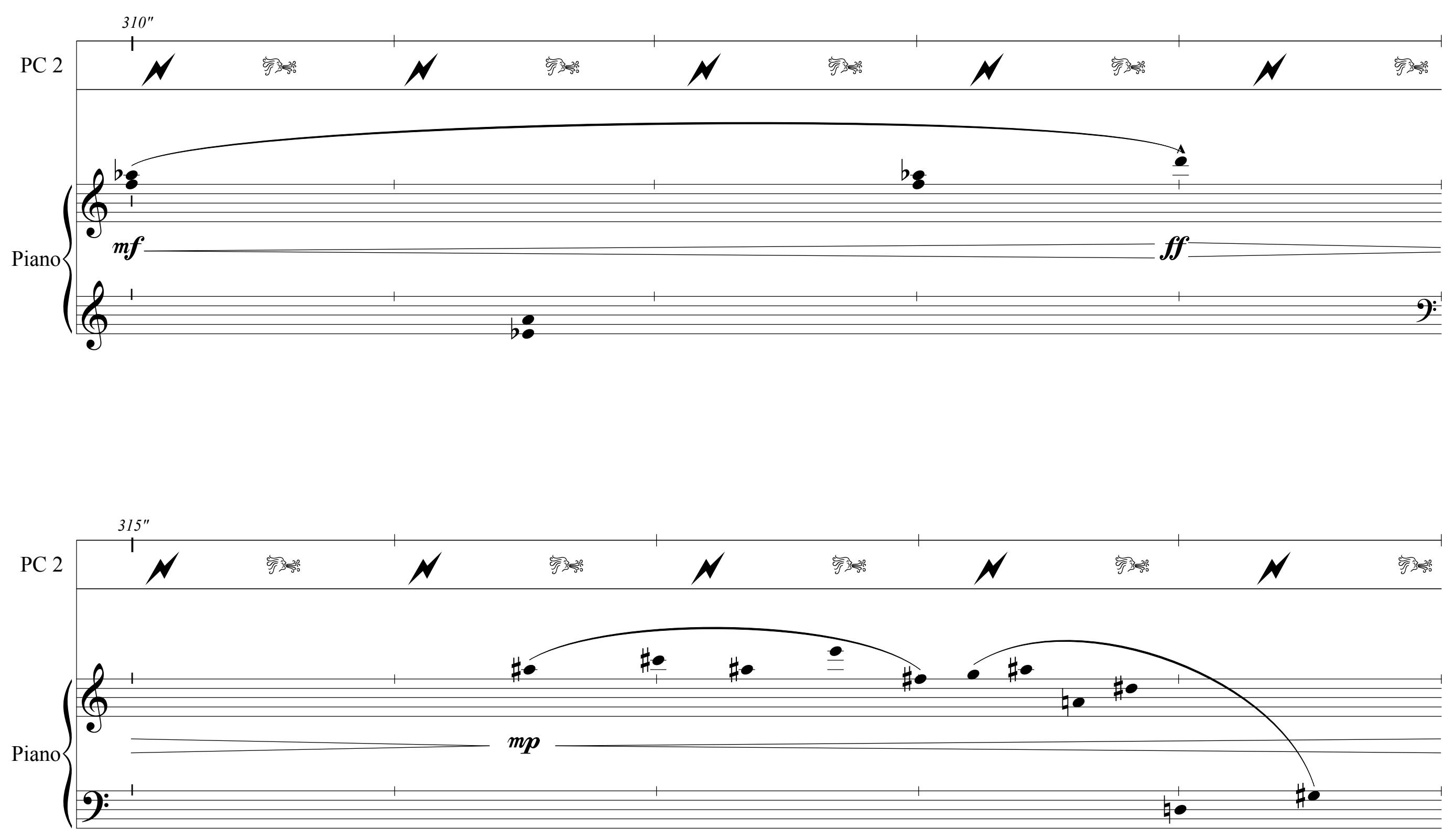
Bogo, Danilo. "Uma cor que desentorte o arco-íris"
Per Musi no. 42, General Topics. 1-50. e224201. DOl 10.35699/2317-6377.2022.36908
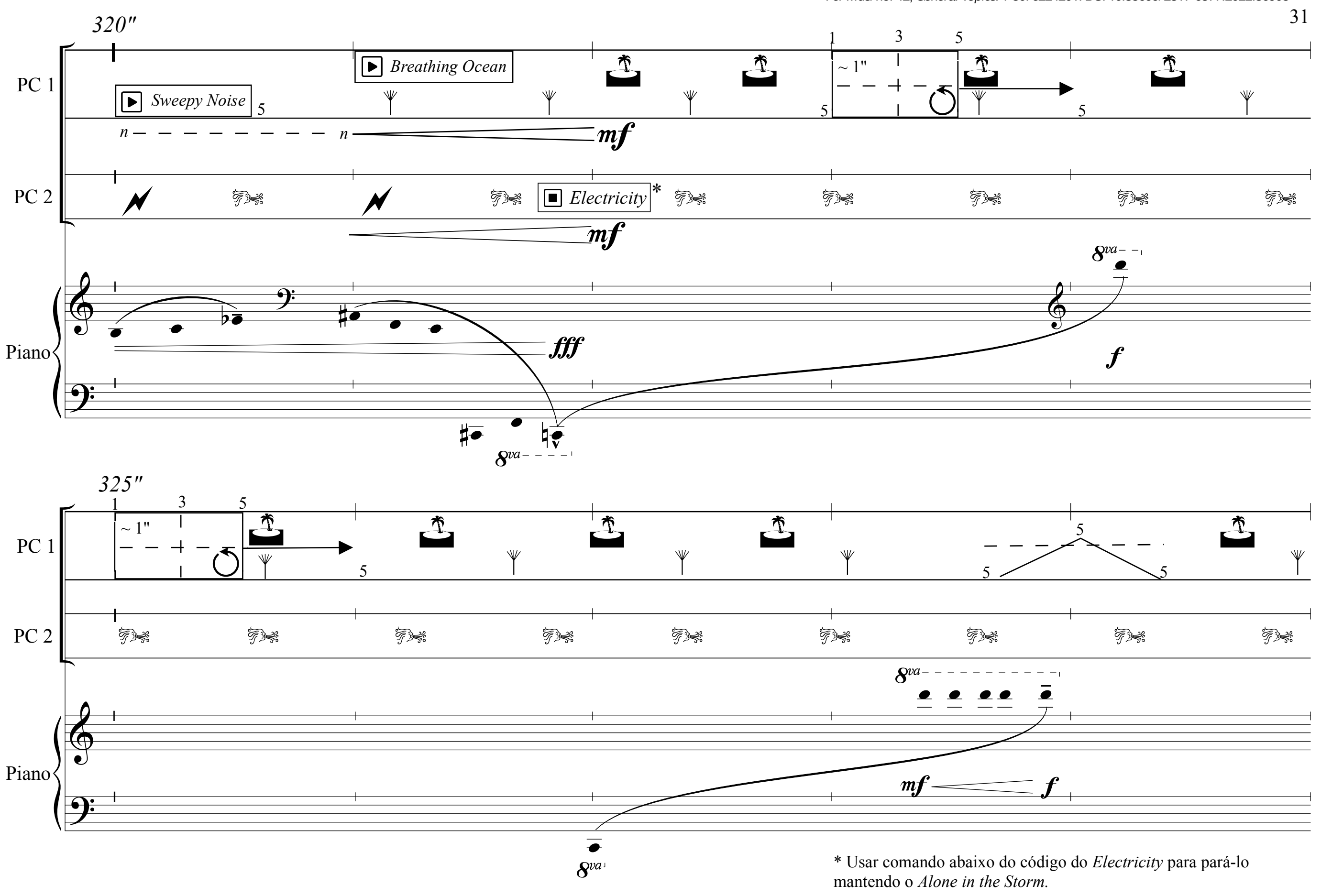


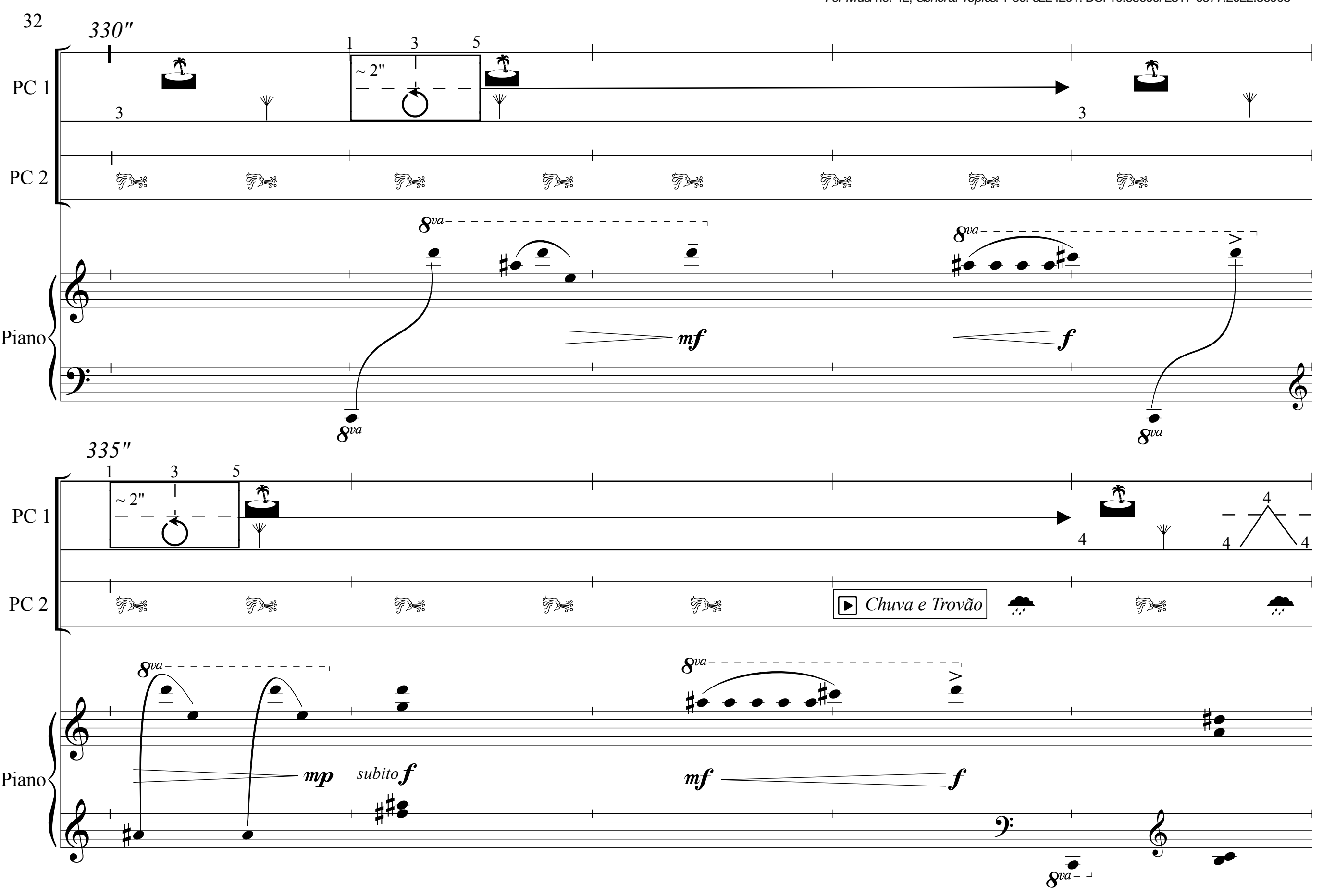


Bogo, Danilo. "Uma cor que desentorte o arco-íris"

Per Musi no. 42, General Topics. 1-50. e224201. DOl 10.35699/2317-6377.2022.36908
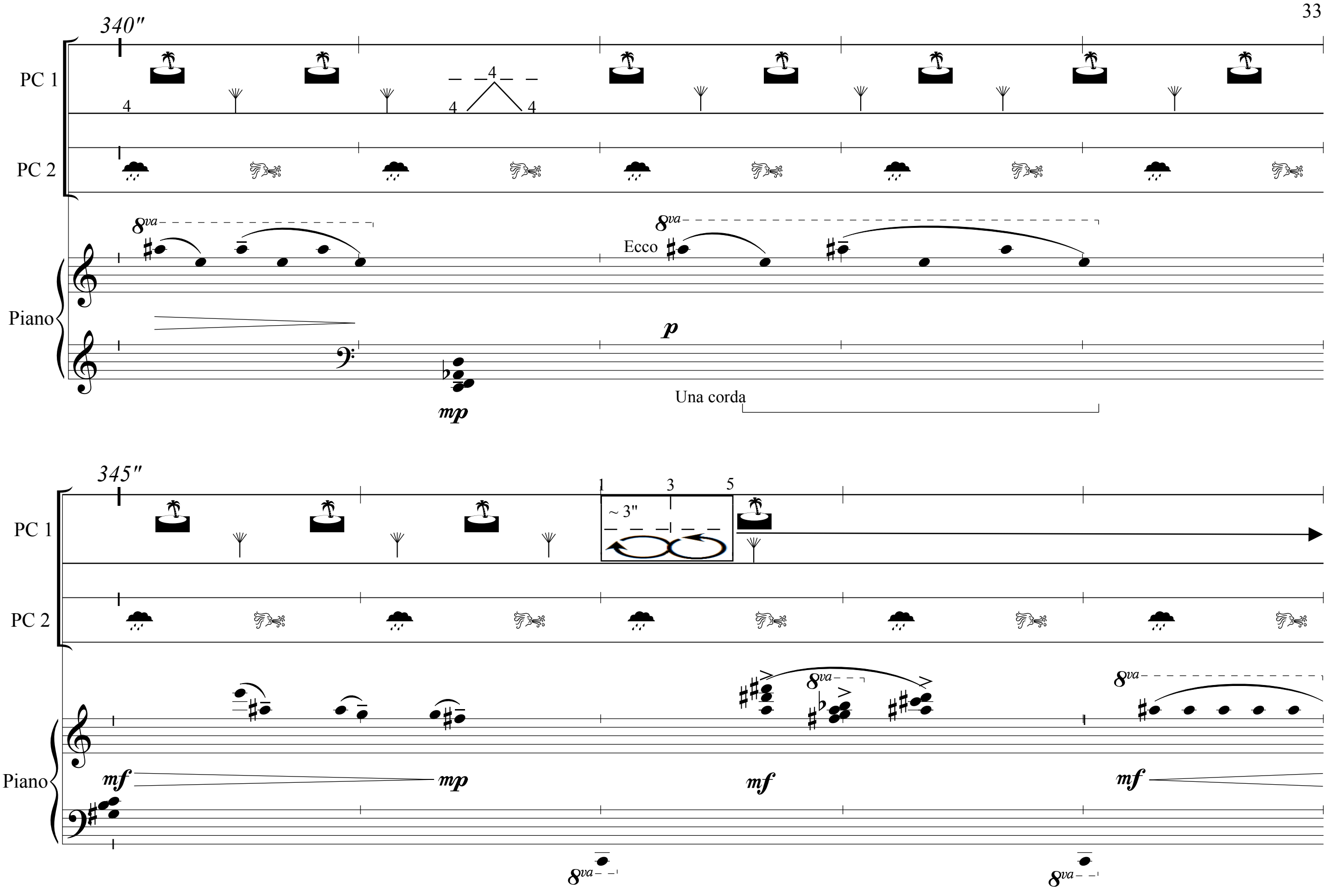

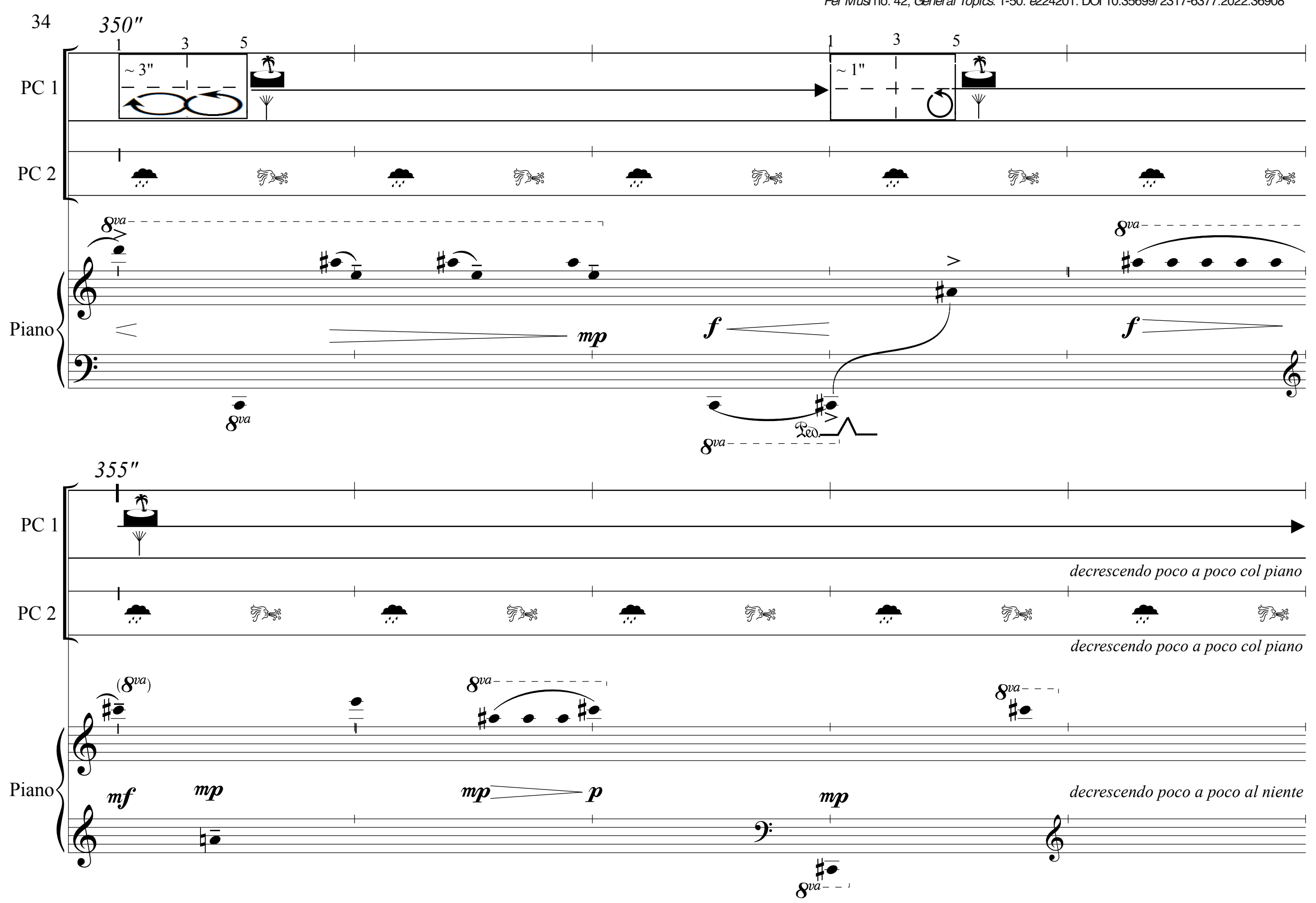
Bogo, Danilo. "Uma cor que desentorte o arco-íris"

Per Musi no. 42, General Topics. 1-50. e224201. DOI 10.35699/2317-6377.2022.36908

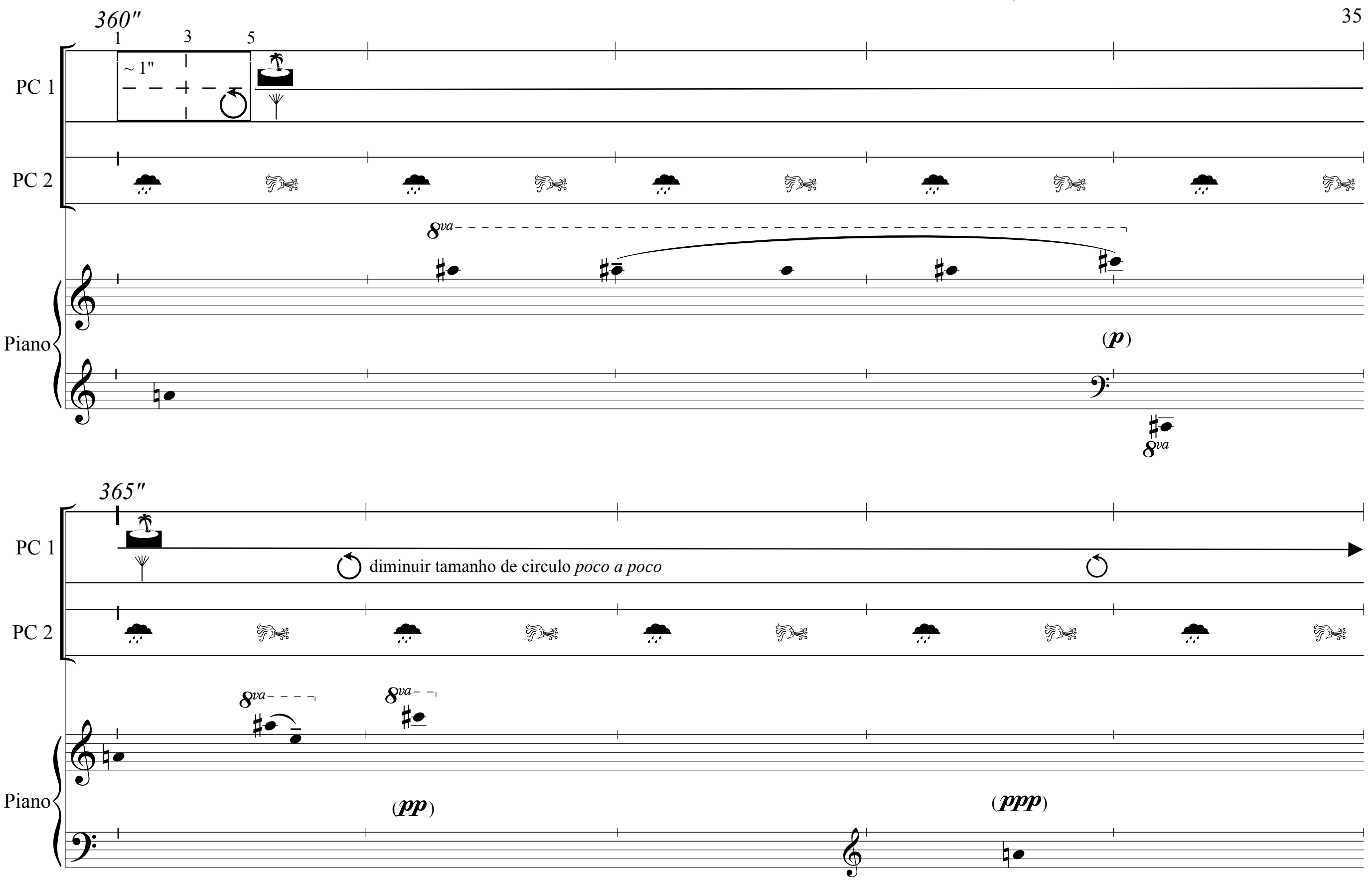




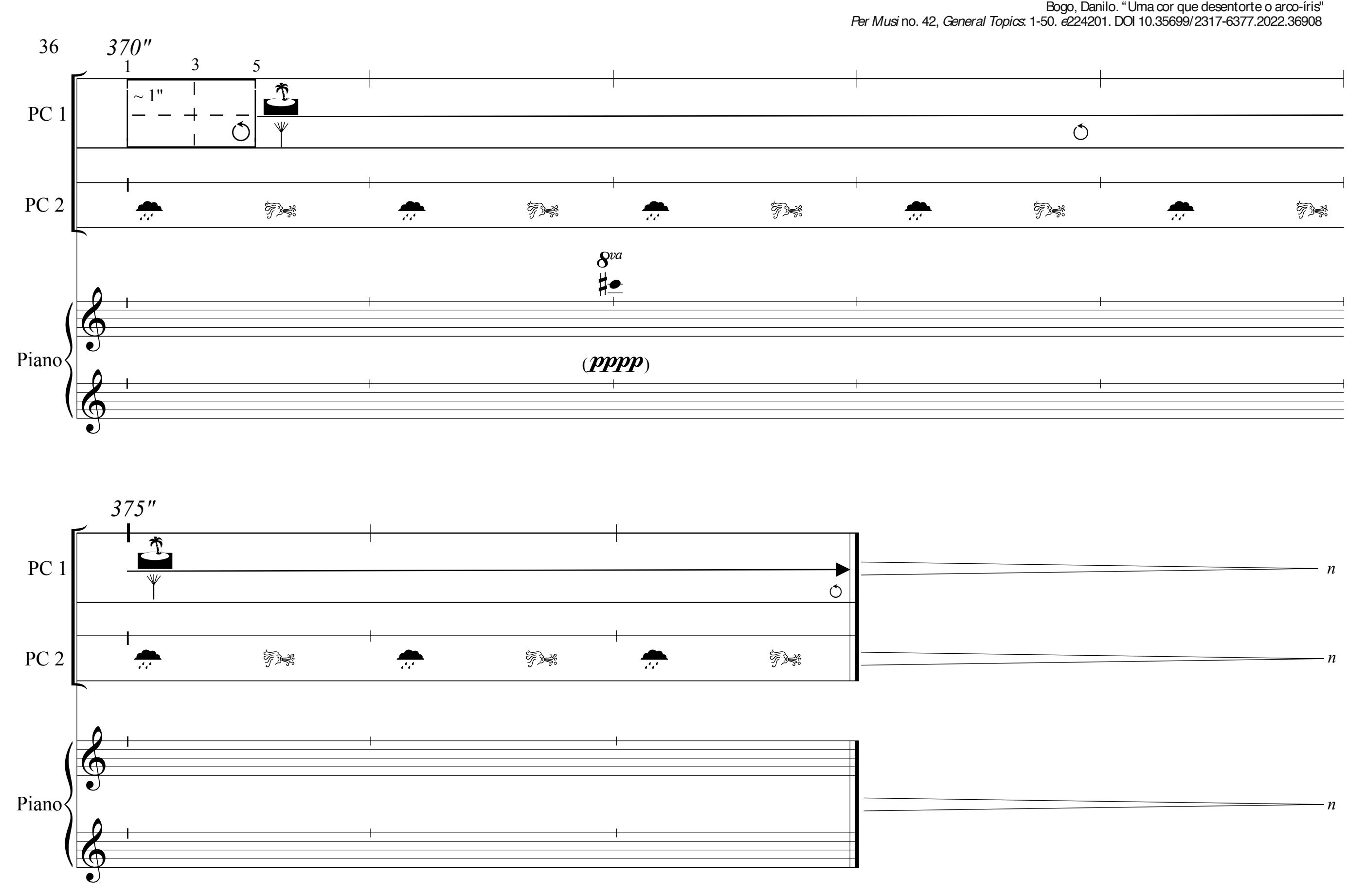

